ANL-80-59

or. 2222

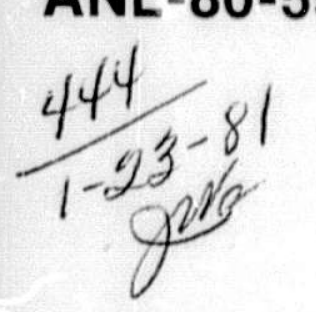

ANL-80-59
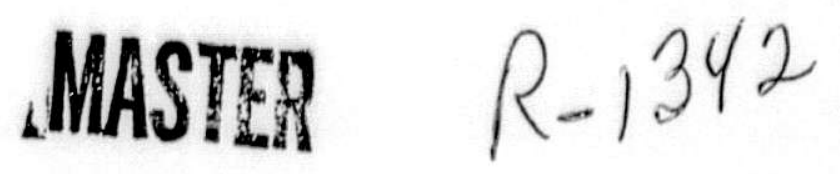

\title{
A STATE-OF-THE-ART REVIEW \\ OF MATERIALS-RELATED PROBLEMS IN \\ FLUE GAS DESULFURIZATION SYSTEMS
}

by

P. S. Maiya

ARGONNE NATIONAL LABORATORY, ARGONNE, ILLINOIS

Prepared for the Office of Fossil Energy

U. S. DEPARTMENT OF ENERGY

under Contract W-31-109-Eng-38 

Distribution Category:

Coal Conversion and Utilization-

Direct Combustion of Coal (UC-90e)

A Ni. $80-59$

ARGONNE NATIONAL LABORATORY

9700 South Cass Avenue

Argonne, Illinois 60439

A STATE-OF-THE-ART REVIEW

OF MATERIALS-REIATED PROBLFMS IN

FLUE GAS DESULFURIZATION SYSTIEMS

by

P. S. Maiya

Materials Science Division

Octoner 1980 

TABLE OF CONTENTS

Page

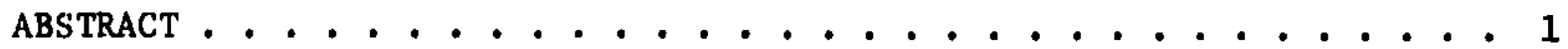

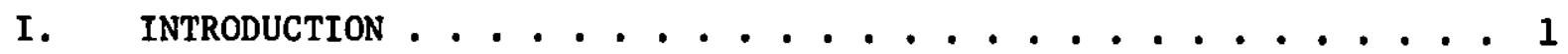

II. FGD PROCESSES ................... 3

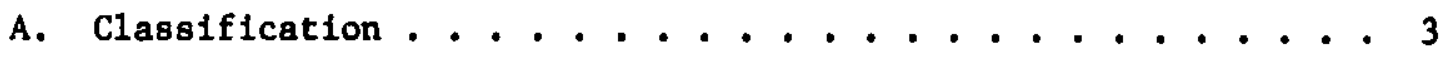

B. Description of the Lime/LImestone System ......... 5

C. Design Considerations for Lime/LImestone Systems . . . . . 6

III. CHARACTERIZATION OF FGD ENVIRONMENTS ............ 6

A. $\mathrm{pH} \ldots \ldots \ldots \ldots \ldots \ldots \ldots$

B. Chlorides ...................11

C. Mechanical and Thermal Consideratior,s ......... 11

D. Current Approaches to Improving FGD Technology . . . . . . 12

IV. SCHEMES FOR SELECTION AND PROTECTION OF WET-SCRUBbER MATERIALS . , 13

A. Mater1al Variables and Experimertal Conditions . . . . . 13

B. Mater181s Used in Current FGD Systems and Their Performance . 17

v. SUMMARY AND CONCLUSTONS ................. 24

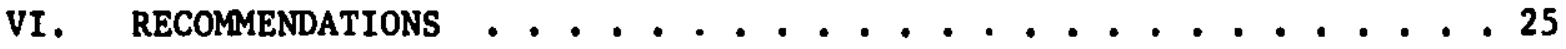

A. Fallure Analys1s ............... 25

B. Research on Mater1als .............. 25

VII. MATERIALS PROGRAM FOR LIME/LIMESTONE SCRUBBER COMPONENTS . . . . 27

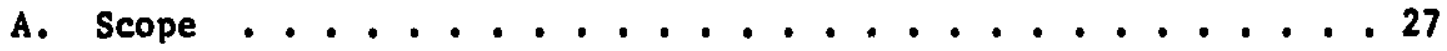

B. Proposed Program ................. 28

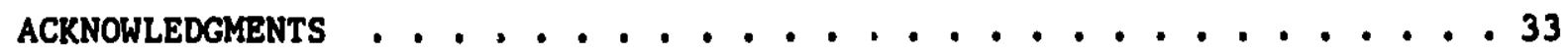
REFERENCES . . . . . . . . . . . . . . . 33 


\section{LIST OF FIGURES}

No.

Title

1. A Schematic Illustration of the Flue-gas Path in a Typical Coal-fired Power Plant . . . . . . . . . . 5

2. Effect of $\mathrm{pH}$ or: solubility of $\mathrm{CaSO}_{3} \cdot 2 \mathrm{H}_{2} \mathrm{n}$ and $\mathrm{CaSO}_{4} \cdot 2 \mathrm{H}_{2} \mathrm{O}$ at $122^{\circ} \mathrm{F}$. . . . . . . . . . . . . . . . . 9

3. Wet Sc rubbing System, Showing Areas of Possible Corrosive Attack . . . . . . . . . . . . . . . 13

4. Effect of Chloride Concentration and $\mathrm{pH}$ on Rate of Localized Attack on Type 316L Stainless Steel . . . . . . 14

5. Effect of Chloride Concentration and $\mathrm{pH}$ on Rate of Localized Attack on Type 317L Stalnless Steel . . . . . . 15

6. Effect of Molybdenum Content on Pitting and Crevice Corrosion of Stalnless Steels . . . . . . . . . . 15

7. Wet Scrubbers for Which Operating Experience is Ava11able . 22

8. Effect of Chloride Concentration and pH on Pitting Rate

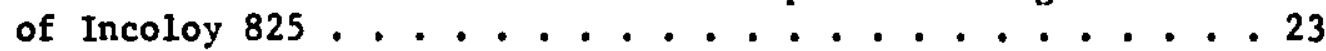

9. Ef fect of Chloride Concentration and pH on Pitting Rate

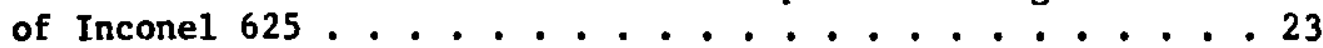




\section{LIST OF TABLES}

No.

Title

Page

I. Composition of a Typical Western Kentucky Coal . . . . . 2

II. Composition of Stack Gas Evolved in Burning Western Kentucky Coal . . . . . . . . . . . . . . . . . 3

III. Leading $\mathrm{SO}_{2}$-remova? Processes . . . . . . . . . . 4

IV. Description of FGD Systems Visited . . . . . . . . 18

V. Major Alloys Currently in Use or Planned for Use in FGD Components . . . . . . . . . . . . . . . 20

VI. Approximate Number of Laboratory and Field Tests That Can Be Performed on Various Materlals Over a Five-year Period with the Assumed Man-Year Support Level . . . . . . . 32 
A STATE-OF-THE-ART REVIEW OF MATERIALS-RELATED PROBLEMS

IN FLUE GAS DESULFURIZATION SYSTEMS

by

P. S. Ma1ya

\section{ABSTRACT}

Th1s report characterizes the chemical and mechanical environments to which the structural components used in flue-gas desulfurization (FGD) are exposed. It summarizes the necessary background information pertinent to various FGD processes currently in use, with particular emphasis on $11 \mathrm{me} / 11$ mestone scrubbing technology, so that the materlals problems and processing variables encountered in FGD systems can be better defined and apprectated. The report also describes the naterials currently used and their performance to date in existing wet scrubbers. There is little doubt that with more extensive use of coal and flue-gas scrubbers by utilities and other segments of private industry, a better understanding of the material fallure mechanisms, performance limitations, and potential problem areas is required for the design of more rellable and cost-effective FGD systems.

To meet the above objectivea, a materlals evaluation program is proposed. The important experimental variables and the number of tests requiret to evaluate a given material are discussed.

\section{INTRODUCTION}

Although sulfur forms several oxides with oxygen, the most stable oxites formed by burning cosl are $\mathrm{SO}_{2}$ and $\mathrm{SO}_{3}$. Because of thermodynamic consideritions and the extremely slow rate of conversion of $\mathrm{SO}_{2}$ to $\mathrm{SO}_{3}, \mathrm{SO}_{2}$ is the principal oulfur-oxygen compound in flue gases from coal-fired bollers. Thue, flue-gas desulfurization (FGD) can be defined, for practical purposes, as the removal of $\mathrm{SO}_{2}$ from these gases befo $\mathrm{d}_{2}$ they enter the atmosphere.

The treatment of flue gases to reduce $\mathrm{SO}_{2}$ emlssions has a history of nearly half a century: The basic principles and process parameters governing FGD were developed at the London Power Company and Imperial Chamical Industries in England during the 19308. However, interest in this work was stimulated in the U.S. during the years 1960-1975 as a result of two events. First, the energy shortage accelerated the ut1lization of high-sulfur coal (Table I), which 18 abundantly available in this country. Second, atrict federal and state alr-quality standarils were imposed on coal-fired power 
Table I. Composition of a Typical Western Kentucky Coal (Ref. 27)

\begin{tabular}{lc}
\hline Constituent & Percent by Welght \\
\hline H & 4.5 \\
N & 1.3 \\
C & $66.0^{\mathrm{a}}$ \\
O & 7.5 \\
S & 3.3 \\
Ash & 12.0 \\
Moisture & 5.4 \\
\hline
\end{tabular}

plants as a necessary step toward $\mathrm{SO}_{2}$ pollution abatement. Faced with the necessity of installing FGD rysteme in most of their coal-fired power plants In the early 1970s, the utility companles confronted many problems, some of which were related to the selection of materials sultable for the highly corrosive and abrasive environment of the scrubber assembly. However, with experfence gained from the operation of large-scale pllot plants, the problems were better defined and research efforts were Initlated toward oolving them. These efforts led to the development of new materials and several protection schemes to enable these materials to withstand a hostile enviroment that contains sulfurous and sulfuric acids, chlorides, and particulateg. Extensive studies of alkall scrubbing for $\mathrm{SO}_{2}$ removal have been conducted $1-8$ through U.S. government-sponsored research and development programs and by several private concerns. As a result of these investigations, lime/1imestone scrubbing technology has advanced faster and has been more fully characterIzed than any other $\mathrm{SO}_{2}$-removal method.

The literature dealing with FGD systems and related problems 18 very extensive and a comprehensive survey of this vast fleld is outside the scope of this report. Instead, the report will review the status of knowledge concerning materials selsction and performance. In particular, our objectives are to characterize the chemical and mechanical environment to which FGD components are exposed, and to define the potential problems and the extent to which they have been overcome or mitigated. 
II. FGD PROCESSES

\section{A. Classification}

Virtually all coal-burning power bollers, except those operating on very low-sulfur western coal, produce $\mathrm{SO}_{2}$ levels above the acceptable limits set by most states (see Table II). Therefore, most power plants are required to use one of the several technologically fegsible $\mathrm{SO}_{2}$-removal processes, whtch are prifefly described in Table III.9-15 Essentlally, most of the methods ${ }^{9-12,16-20}$ involve scrubbing a high-SO 2 gas with some type of alkali materlal such as lime or soda ash. FGD methods can be classified as either throwaway or recovery processes, based upon the end product derived after the removal of $\mathrm{SO}_{2}$. The throwaway processes produce a by-product sludge, which must be either deposited in a nearby pond or landfill or trucked to remote disposal sites. Recovery processes yleld a usable product, which is most often sulfur but can also be sulfuric acid, a fertilizer base compound, or gypsum. FGD methods can also be classifled as dry or wet, with reference to the medium used for $\mathrm{SO}_{2}$ absorption; the most widely used and demonstrated processes are of the wet type.

Table II. Composition of Stack Gas Evolved in Burning Western Kentucky Coal (Ref. 27)

\begin{tabular}{lcc} 
Constituent & Fcrmula & $\begin{array}{c}\text { Percent by } \\
\text { Volume }\end{array}$ \\
\hline N1trogen & $\mathrm{N}_{2}$ & 74.6 \\
Carbon dioxide & $\mathrm{CO}_{2}$ & 12.6 \\
Oxygen & $\mathrm{O}_{2}$ & 4.9 \\
Water vapor & $\mathrm{H}_{2} \mathrm{O}$ & 7.8 \\
Sulfur oxides & & 0.22 \\
Sulfur dioxide & $\mathrm{SO}_{2}$ & 0.001 \\
Sulfur trioxide & $\mathrm{SO}_{3}$ & 0.04 \\
N1trogen oxides & $\mathrm{NO}_{\mathrm{x}}(\mathrm{x}=1,3)$ & $36 \mathrm{~g} / \mathrm{sCF}$ \\
\hline Particulate matter & &
\end{tabular}


Table III. Leading $\mathrm{SO}_{2}$-removal Processes

\begin{tabular}{|c|c|c|c|}
\hline Process & Operat InR Principles & $\begin{array}{l}\mathrm{SO}_{2} / \text { Particulate } \\
\text { Removal Efficiency }\end{array}$ & Couments \\
\hline Line/Linescone & $\begin{array}{l}\text { Wet absorption in a slurry } \\
\text { of } \mathrm{CaO}_{\mathrm{CaCO}} \text {; end products } \\
\text { are insoluble sulfites and } \\
\text { sulfates, which are disposed } \\
\text { of as a vaste. }\end{array}$ & $\begin{array}{l}\text { Up to } 90 \% \mathrm{SO}_{2} \text { removal } \\
\text { and } 99 \% \text { fly-ash removal } \\
\text { in nost scrubbers. }\end{array}$ & $\begin{array}{l}\text { Probably the cheapest of existing } \\
\text { processes, but is associated with } \\
\text { waste, scalling, and water pollution } \\
\text { problems. }\end{array}$ \\
\hline $\begin{array}{l}\text { Double } \\
\text { Alkall } \\
\text { Droceas }\end{array}$ & $\begin{array}{l}\text { Wet absorption In scrubber } \\
\text { contafning Non; reactants } \\
\text { are soluble; react fon pro- } \\
\text { ducts precipitated and re- } \\
\text { moved from recycled resctant } \\
\text { solution outside of scrubber; } \\
\text { end product is gypsum. }\end{array}$ & $\begin{array}{l}\text { High-ef flclency }(>90 z) \\
\mathrm{SO}_{2} \text { removal and high } \\
\text { particulate removal as } \\
\text { above. }\end{array}$ & $\begin{array}{l}\text { Scaling is a problem in the pre- } \\
\text { cipitator, but not in the scrubber. }\end{array}$ \\
\hline $\begin{array}{l}\text { Nagnesia } \\
\text { Serubbing }\end{array}$ & $\begin{array}{l}\text { Wet absorption by Hgo slurry; } \\
\text { fly ash removed prior to or } \\
\text { after scrubbing; Hgo re- } \\
\text { generated by salcining with } \\
\text { carbon. } \mathrm{SO}_{2} \text { by-product can } \\
\text { be cotverted co sulfuric } \\
\text { ac1d or sulfur. }\end{array}$ & $\begin{array}{l}90 z \mathrm{SO}_{2} \text { removal; } \\
\text { part } 1 \text { culate resioval } \\
\text { as required by pre- } \\
\text { scrubber. }\end{array}$ & $\begin{array}{l}\text { May be more reliable than lime/lime- } \\
\text { stone process; no known waste dis- } \\
\text { posal problems; higher cost for } \\
\text { regeneration; warketiog of sulfur } \\
\text { products required. }\end{array}$ \\
\hline $\begin{array}{l}\text { Catalytic } \\
\text { Oxidation }\end{array}$ & $\begin{array}{l}\mathrm{SO}_{2} \text { is converted to } \mathrm{SO}_{3} \text { in } \\
\text { the presence of } \mathrm{V}_{2} \mathrm{O}_{5} \text { catalyst } \\
\text { and } \mathrm{SO}_{3} \text { is comverted to } \\
\text { sulfuric acid. }\end{array}$ & $\begin{array}{l}80-90 \% \mathrm{SO}_{2} \text { removal; } \\
\text { particulates removed } \\
\text { prior to conversion } \\
\text { from } \mathrm{SO}_{2} \text { to } \mathrm{SO}_{3} \text {. }\end{array}$ & Catalytic oxidation occurs at $850^{\circ} \mathrm{F}$. \\
\hline $\begin{array}{l}\text { Well-nea-Lord/ } \\
\mathrm{SO}_{2} \text { Reduction }\end{array}$ & $\begin{array}{l}\mathrm{SO}_{2} \text { is absorbed by } \mathrm{Ma}_{2} \mathrm{SO}_{3} \text {. } \\
\text { recovered by heat ing, and } \\
\text { reduced to } \mathrm{S} \text {. }\end{array}$ & $\begin{array}{l}>90 \% \mathrm{SO}_{2} \text { removal; } \\
\text { part Iculate removal } \\
\text { by prescrubber. }\end{array}$ & $\begin{array}{l}\text { Wellman-Lord process produces con- } \\
\text { centrated } \mathrm{SO}_{2} \text { by thermal stripping } \\
\text { of } \mathrm{NaHSO}_{3} \cdot \mathrm{SO}_{2} \text { is reduced to } \mathrm{S} \\
\text { with natural gas. }\end{array}$ \\
\hline Citrate & $\begin{array}{l}\mathrm{SO}_{2} \text { is absorbed by sodium } \\
\text { citrate and -itric acid aad } \\
\text { rencted utth } \mathrm{H}_{2} \mathrm{~S} \text { to produce } \\
\text { elemental sulfur. }\end{array}$ & $\begin{array}{l}907 \mathrm{SO}_{2} \text { renoval; } \\
\text { part } 1 \text { culate rewoval by } \\
\text { prescrubber. }\end{array}$ & \\
\hline $\begin{array}{l}\text { ary } \\
\text { absorption }\end{array}$ & $\begin{array}{l}\text { The absorption mediun is } \\
\text { char: the absorbed } \mathrm{SO}_{2} \\
\text { is recovered and reduced } \\
\text { to elewental sulfur. }\end{array}$ & $\begin{array}{l}\text { Lower efficiency of } \\
\mathrm{SO}_{2} \text { rewoval than the } \\
\text { above processes. }\end{array}$ & $\begin{array}{l}\text { Minimum water use, minimum waste } \\
\text { disposal, no stack reheating. }\end{array}$ \\
\hline Dry Scrubbing & $\begin{array}{l}\mathrm{Na}_{2} \mathrm{CO}_{3} \text { solution spraved into } \\
\text { the fiue gas in a drying } \\
\text { chamber to produce } \mathrm{Na}_{2} \mathrm{SO}_{3} / \\
\mathrm{Na}_{2} \mathrm{SO}_{4} \text { powder. }\end{array}$ & $75-85 \% \mathrm{SO}_{2}$ removal. & $\begin{array}{l}\text { No reheating and no sludge-handling } \\
\text { problex. Apfificable to low-sulfur } \\
\text { coals. }\end{array}$ \\
\hline
\end{tabular}




\section{B. Description of the Lime/Limestone System}

As pointed out earlier, lime/1imestone scrubbing is the most highly developed and widely applied FGD method in current use. In fact, this method is used in $290-95 \%$ of present installations (including those under construction). From a materlals viewpoint, the lime/limestone scrubbers are the most useful systems to investigate because of the extensfve operating experience available.16,21,22 Many of the 1ime/1imestone FGD system components (e.g., prescrubbers, absorbers, spray nozzles, mist eliminators, reheaters, fans, ducts, expansion joints, dampers, pumps, plping, valves, tanks, thickeners, ag1tators, rakes, and filters) are also used in some of the more advanced processes.

The three main components of the lime/11mestone scrubbing system are the scrubber, the reaction tank, and the thickener. The function of the scrubber is to promote intimate mixing of the $\mathrm{SO}_{2}$-laden flue gas and the lime/11mestone, which is introduced into the scrubber as a slurry of 5-15 wt.\% solids in water. The exhaust gas from the bollers passes through the scrubber, undergoes cleaning, and then proceeds to the stack (see Fig. 1). The reaction tank forms the receptacle for the reacted materlals discharged from the scrubber. The chemicai reactions between the $\mathrm{SO}_{2}$ and the lime/limestone slurry go to completion here. Reusable slurry is sent back to the scrubber, and makeup slurry is added to the tank as needed. The reacted slurry is then transported to the thickener, where the solids are concentrated by sedimentation and removed to 3 pond or landfill. The clarified water is returned to the scrubber for reuse.

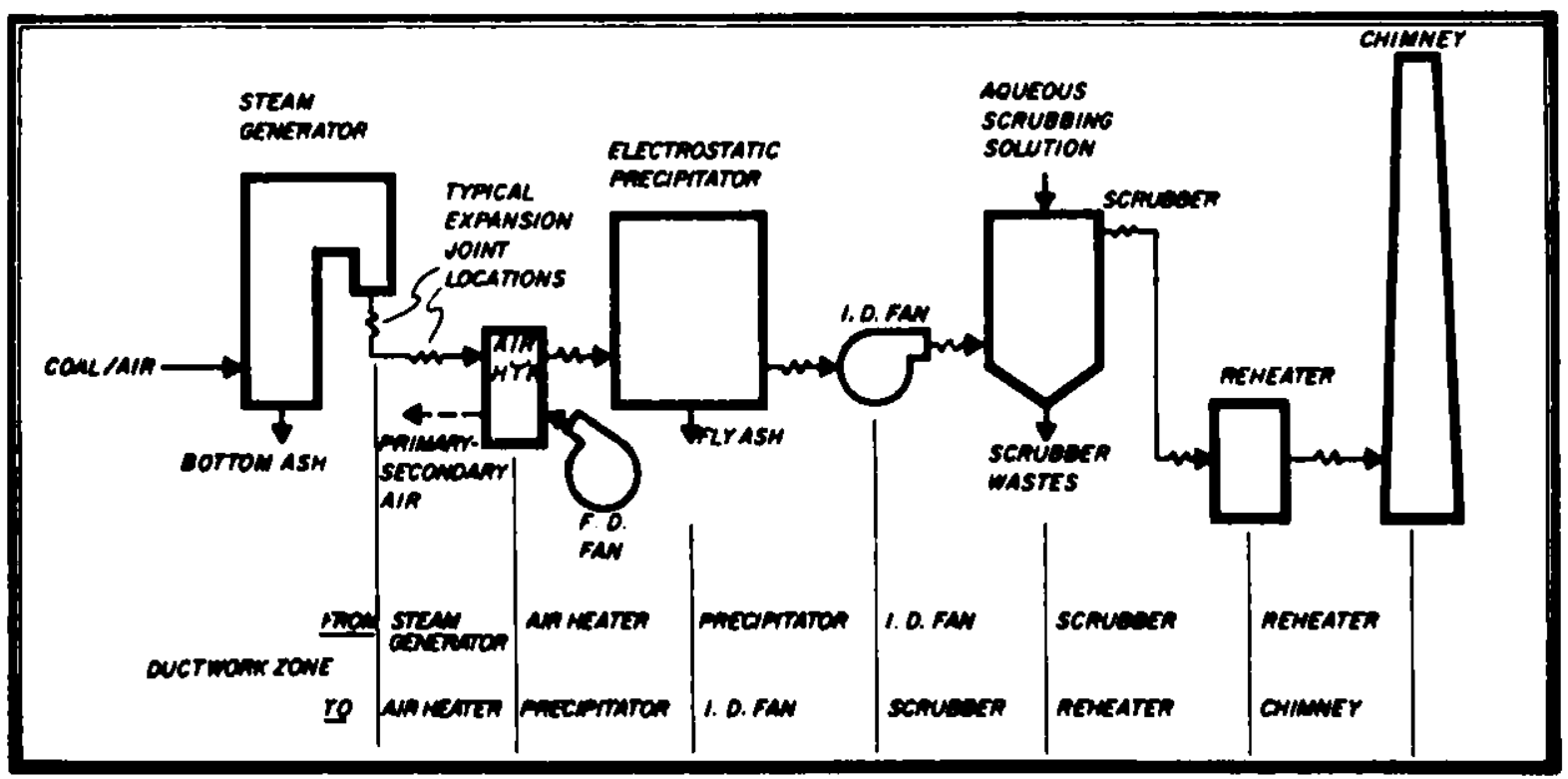

Fig. 1. A Schematic Illustration of the Flue-gas Path in a Typical Coal-fired Power Plant. From Power Engineering, September 1976, Volume 80, Number 9, pages 52-55. 


\section{Design Considerations for Lime/Limestone Systems}

The chief criterion for choosing among the several available types of lime/limestone scrubbers (venturi, spray tower, open grid, etc.) is the high efficlency of $\mathrm{SO}_{2}$ removal. High efficlency has been obtained with twostage and multistage venturi scrubbers. However, the design of a specific system depends on many varlables such as the sulfur and ash content of the coal, required turndown capabllity, type of waste disposal avallable, fly-ash content (fly ash can be removed elther before $\mathrm{SO}_{2}$ or at the same time), 11quid-to-gas (L/G) ratio, $\mathrm{pH}$ control, \% solids in slurry, lime/limestone particle size, number of stages, and gas-11quid interface.23,24 For example, the propensity for scaling increases with a decrease in the L/G ratio. However, the rate of absorption can be boosted by increasing the gas-1iquid interface. Many of the parameters mentfoned above are interrelated and require a study to optimize the efficiency of operation.

Another operating consideration which affects the choice of materials for 1 ime/11mestone systems is whether the stack gas is reheated.25,26 As the flue gas passes through the absorber and demister, it is humidifled and cooled to $120-130^{\circ} \mathrm{F}$, thus losing its buoyancy. For example, under standard atmospher conditions, flue gas at $310^{\circ} \mathrm{F}\left(154^{\circ} \mathrm{C}\right)$ has a velocity of $42 \mathrm{fps}$ $(13 \mathrm{~m} / \mathrm{s})$... a stack, which is typically $16.5 \mathrm{ft}(5 \mathrm{~m})$ in. dlameter and $300 \mathrm{ft}(91 \mathrm{~m}) \mathrm{high}$, whereas the same gas at $125^{\circ} \mathrm{F}\left(51^{\circ} \mathrm{C}\right)$ has a velocity of only $32 \mathrm{fps}(9.8 \mathrm{~m} / \mathrm{s})$. Therefore, the wet-scrubbed gas must be reheated to regain 1 ts buoyancy in the stack; this decreases the visible plume and amounts of mist and condensate (acid rain) in the stack. The reheating procedure also reduces corrosion of ducts, fans, and stacks downstream by keeping the temperature of the gas above its dew point.

FGD systems are also provided with several expansion joints (see F1g. 1). In addition to relleving thermal stresses, they perform a number of functions such as isolation of mechanical vibrations, reduction in mechanical noise, and compensation for misalignment. Since these foints are subjected to varying corrosive and erosive conditions at temperatures ranging from 50 to $450^{\circ} \mathrm{C}$, evaluation of materials for them is very important.

\section{CHARACTERIZATION OF FGD ENVIRONMENTS}

The most Important parameters governing the corrosion of materials In scrubber environments are the $\mathrm{pH}$ and chloride content of the 11quid and slurry. However, the corrosion process is further accentuated by oxygen and crevice concentration effects as well as by erosive conditions prevalent in the environment, mechanical loading, and temperature excursions. In this section, the chemical, mechanical, and thermal environments of 1 ime/limestone and other scrubbing systems will be examined to provide a basis for defining the potential materials problems. 
A. $\underline{\mathrm{pH}}$

The $\mathrm{pH}$ of the solutions used in the scrubbing assembly is predominiatly determined by the chemistry of the FGD process, the 1mpurity content $i$, oal and water, and the chemicals used in the system. In practic. wis normal operating conditions, the pH can vary from $\sim 3$ (highly acidic) to " sasic), depending on the system and the location within it. These dil: :-ices in $\mathrm{pH}$ should affect the operation of the scrubber with regard to both scale formation and corrosion problems. Thus, a variety of materials capable of withstanding solutions that vary from acidic to alkaline are needed. The requirements for $\mathrm{pH}$ control associated with several different scrubbing processes are described in the following subsections.

\section{Lime/Limestone Process}

A knowledge of the detailed mechanism for wet scrubbing with lime $(\mathrm{CaO})$ and limestone $\left(\mathrm{CaCO}_{3}\right)$ is important for understanding the operation of the system and the associated materials problems. Fellman and Cheremisinoff 27,28 have postulated the following reaction sequence for scrubbing with $\mathrm{CaO}$ :

$$
\begin{aligned}
& \mathrm{SO}_{2}(\mathrm{~g})+\mathrm{H}_{2} \mathrm{O} \rightarrow \mathrm{H}_{2} \mathrm{SO}_{3} \\
& \mathrm{H}_{2} \mathrm{SO}_{3} \rightarrow \mathrm{H}^{+}+\mathrm{HSO}_{3}^{-} \\
& \mathrm{CaO}+\mathrm{H}_{2} \mathrm{O} \rightarrow \mathrm{Ca}(\mathrm{OH})_{2} \\
& \mathrm{Ca}(\mathrm{OH})_{2}+\mathrm{Ca}^{2+}+2(\mathrm{OH})^{-} \\
& \mathrm{Ca}^{2+}+\mathrm{HSO}_{3}^{-}+2 \mathrm{H}_{2} \mathrm{O} \rightarrow \mathrm{CaSO}_{3} \cdot 2 \mathrm{H}_{2} \mathrm{O}^{-}+\mathrm{H}^{+} \\
& 2 \mathrm{H}^{+}+2(\mathrm{OH})^{-} \rightarrow 2 \mathrm{H}_{2} \mathrm{O}
\end{aligned}
$$

Summation of reactions (1-6) leads to the overall reaction

$$
\begin{aligned}
\mathrm{CaO}+\mathrm{SO}_{2}+2 \mathrm{H}_{2} \mathrm{O}+ & \mathrm{CaSO}_{3} \cdot 2 \mathrm{H}_{2} \mathrm{O} \\
& \left(\Delta \mathrm{G}_{300 \mathrm{~K}}=-44.5 \mathrm{kcal} / \mathrm{mole}\right),
\end{aligned}
$$

where $\Delta G$ is the free energy change of the reaction at room temperature. 
The postulated chemical reactions for scrubbing with $\mathrm{CaCO}_{3}$ are 28

$$
\begin{aligned}
& \mathrm{SO}_{2} \mathrm{(g}+\mathrm{H}_{2} \mathrm{O}+\mathrm{H}_{2} \mathrm{SO}_{3} \\
& \mathrm{H}_{2} \mathrm{SO}_{3}+\mathrm{H}^{+}+\mathrm{HSO}_{3}^{-} \\
& \mathrm{H}^{+}+\mathrm{CaCO}_{3}+\mathrm{Ca}^{2+}+\mathrm{HCO}_{3}^{-} \\
& \mathrm{Ca}^{2+}+\mathrm{HSO}_{3}^{-}+2 \mathrm{H}_{2} \mathrm{O}+\mathrm{CaSO}_{3} \cdot 2 \mathrm{H}_{2} \mathrm{O}+\mathrm{H}^{+} \\
& \mathrm{H}^{+}+\mathrm{HCO}_{3}^{-}+\mathrm{H}_{2} \mathrm{CO}_{3} \\
& \mathrm{H}_{2} \mathrm{CO}_{3} \rightarrow \mathrm{CO}_{2}+\mathrm{H}_{2} \mathrm{O}
\end{aligned}
$$

Sumation of reactions (8-13) leads to the overall reaction

$$
\begin{aligned}
\mathrm{CaCO}_{2}+\mathrm{SO}_{2}+2 \mathrm{H}_{2} \mathrm{O} \rightarrow & \mathrm{CaSO}_{3} \cdot 2 \mathrm{H}_{2} \mathrm{O}+\mathrm{CO}_{2} \\
& \left(\Delta \mathrm{G}_{300 \mathrm{~K}}=-13.4 \mathrm{kcal} / \mathrm{mole}\right)
\end{aligned}
$$

Although both overall reactions are thermodynamically favoraile, reaction (7) is much more favorable than reaction (14). However, limestone is less expensive and more readily avallable than lime, and the low efficiency of reaction (14) can be Improved by proper scrubber design.

The effect of $\mathrm{pH}$ on these two processes is complex. For example, simultaneously with the above reactions, sulfite ion undergoes oxidation by dissolved oxygen in the absorbent slurry to form sulfate Ion:

$$
2 \mathrm{SO}_{3}^{2-}+\left(\mathrm{O}_{2}\right) \rightarrow 2 \mathrm{SO}_{4}^{2-}
$$

Because of the excess oxygen in the flue gas, the concentratiun of dissolved oxygen in the slurry 18 approximately constant, so that the formation of $\mathrm{SO}_{4}{ }^{2-}$ by reaction (15) depends on the avallability of $\mathrm{SO}_{3}{ }^{2-}$. In practice, calclum sulfite and sulfate coprecipitate in the system. From the relationship between solubility and $\mathrm{pH}$ for calclum sulfite and sulfate (Fig. 2), it is clear that sulfite is more soluble in water than sulfate at $10 \mathrm{w} \mathrm{pH}$, and acid conditions therefore enhence sulfate production. This is undesirable because $\mathrm{CaSO}_{4}$ forms a hard scale. (This problem can be mitigated somewhat by increasing the L/G ratio.) However, if the $\mathrm{pH}$ is too high, the increased 


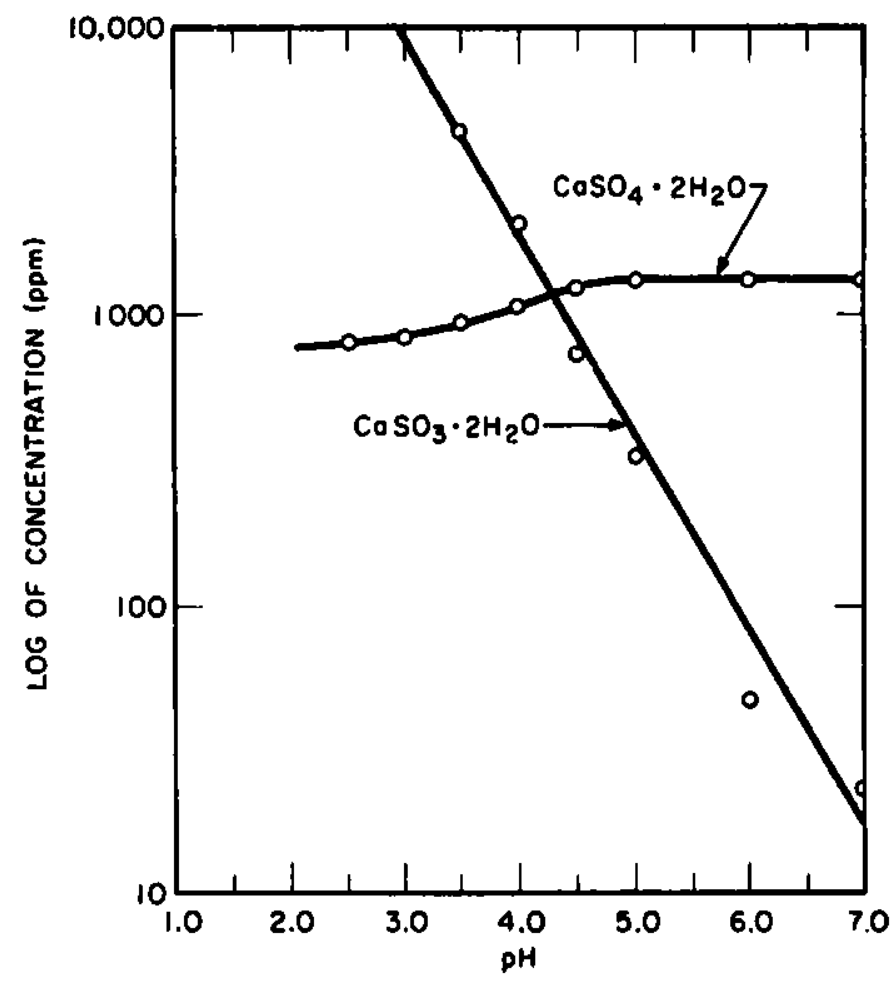

Fig. 2. Effect of pH on Solubility of $\mathrm{CaSO}_{3} \cdot 2 \mathrm{H}_{2} \mathrm{O}$ and $\mathrm{CaSO}_{4} \cdot 2 \mathrm{H}_{2} \mathrm{O}$ at $122^{\circ} \mathrm{F}$ (Ref. 28).

precipitation of $\mathrm{CaSO}_{3}$ causes a pheiomenon known as soft pluggage. Also, in both the lime and limestone reaction sequences, there is a critical step [reactions (5) and (11), respectively] in which $\mathrm{Ca}^{2+}$ captures $\mathrm{SO}_{2}$ from the solution. In the 1 imestone system, formation of $\mathrm{Ca}^{2+}$ depends on $\mathrm{H}^{+}$and $\mathrm{CaCO}_{3}$, whereas in the lime system, formation of $\mathrm{Ca}^{2+}$ depends only on the presence of 11me. These results imply that the optimal $\mathrm{pH}$ (5-6) for operation of a 1 imestone system is lower than that for a lime system.

\section{Double Alkali Process}

The scaling in 1ime/11mestone scrubbers caused by the presence of insoluble calclum sulfite/sulfate is eliminate in the scrubbing part of the double-alkali process (Table III). Sodlum hydroxide is used for scrubbing and the resultant liquor is reacted with calcium-liased alkali to precipitate $\mathrm{CaSO}_{4}$ for disposal and to regenerate the sodium-based alkall. The chemical reactions associated with the scrubbing and regeneration processes are as follows:

$$
\begin{aligned}
& \mathrm{NaOH}+\mathrm{SO}_{2}+\mathrm{Na}_{2} \mathrm{SO}_{3}+\mathrm{H}_{2} \mathrm{O} \\
& \mathrm{Na}_{2} \mathrm{SO}_{3}+\mathrm{SO}_{2}+\mathrm{H}_{2} \mathrm{O}+2 \mathrm{NaHSO}_{3} \quad \text { scrubbing }
\end{aligned}
$$




$$
\begin{aligned}
& \mathrm{Na}_{2} \mathrm{SO}_{3}+\frac{1}{2} \mathrm{O}_{2} \rightarrow \mathrm{Na}_{2} \mathrm{SO}_{4} \\
& \mathrm{NaHSO}_{3}+\mathrm{Ca}(\mathrm{OH})_{2} \rightarrow \mathrm{NaOH}+\mathrm{CaSO}_{4}+\mathrm{H}_{2} \mathrm{O} \\
& \mathrm{Na}_{2} \mathrm{SO}_{3}+\mathrm{Ca}(\mathrm{OH})_{2}+2 \mathrm{NaOH}+\mathrm{CaSO}_{3} \quad \text { regenerating } \\
& \mathrm{Na}_{2} \mathrm{SO}_{4}+\mathrm{Ca}(\mathrm{OH})_{2} \rightarrow 2 \mathrm{NaOH}+\mathrm{CaSO}_{4}
\end{aligned}
$$

One of the primary reasons for the development of the alkall process was to obviate the scaling problem. However, scaling can occur $f$ the regenerator, and the problems encountered there are similar to those in the $11 \mathrm{me} / 1$ imestone system.

\section{Magnesia Process}

Magnes la scrubbing (see Table I) utilizes a magnesla slurry to forin magneslum sulfite (and sulfate). The slurry solutions are evaporated to obtain $\mathrm{MgSO}_{3}$ and $\mathrm{MgSO}_{4}$ crystals. These crystals, up a calcination at 1475$1832^{\circ} \mathrm{F}$ in the presence of coke, regenerate $\mathrm{MgO}$ and release $\mathrm{SO}_{2}$, which 1 s converted to sulfuric acid. In the MgO system, fly ash and other particulates are removed from the flue-gas stream prior to the scrubbing operations by efther electrostatic precipitators or primary scrubbers. In the magnesia scrubbing system, the pH perlodically undergoes excursions from 0.5 to 9 and the corrosion problems appear to be similar to those of systems described earlier in the report.

\section{Citrate Process}

The citrate process is a regenerable process (Table I) that yields high-quality sulfur as a by-product. Sulfur dloxide from the flue gas 18 absorbed by sodium citrate + citric acid. Citrate acts as a buffering agent, which facilitates control of the process $\mathrm{pH}--$ a desirable feature from the viewpoint of materials performance -- and shifts the equilibrium to the right as shown below: 18

$$
\begin{aligned}
& \mathrm{SO}_{2}+\mathrm{H}_{2} \mathrm{O} \rightarrow \mathrm{HSO}_{3}^{-}+\mathrm{H}^{+} \\
& \mathrm{Cit}^{2-}+\mathrm{H}^{+}+\mathrm{HClt}^{2-} \\
& \mathrm{HClt}^{2-}+\mathrm{H}^{+} \rightarrow \mathrm{HClt}^{-}
\end{aligned}
$$

The $\mathrm{SO}_{2}$ laden liquor from the absorber is brought into contact with $\mathrm{H}_{2} \mathrm{~S}$ in a reactor at atmospheric pressure and $150^{\circ} \mathrm{F}$, and all the $\mathrm{SO}_{2}$ is converted to sulfur and water: 


$$
2 \mathrm{H}_{2} \mathrm{~S}+\mathrm{SO}_{2}+3 \mathrm{~S}+2 \mathrm{H}_{2} \mathrm{O}
$$

It is claimed that this process consumes less chemicals and less power than lime/11mestone scrubbing (power consumption increases with an increase in $L / G ; L / G=7$ for citrate and 100 for 1 imestone scrubbing). Also, the citrate process creates no sludge-handling problem. Insufficlent operating expertence exists to evaluate the economics and reliability of the process, although there is sufficient incentive for a long-term study of this process.

\section{B. Chlorides}

The FGD environment is not only acidic, but is ricis in highly soluble chlorides dertved from several sources. Chlorine is a minor constituent of coal. Luring coal combustion, chlorine enters the gas phase predominantly as $\mathrm{HCl}$, which can attain a concentration of as much as $100 \mathrm{ppm}$ in the flue gas; the chlorine also forms inorganic chlorides in the particulate matter entrained in the flue gas. Most of the $\mathrm{HCl}$ and chlorides in the gas enter the FGD system. Chlorides are also produced by the scrubbing materials. For example, if $\mathrm{MgO}$ scrubbing is used, magnestum chloride is formed. In addition, chlorides in the form of $\mathrm{HCl}$ and $\mathrm{NaCl}$ can enter the scrubbing system as impurities in the makeup water. In order to minimize water pollution, cloged-loop rectrculating systems are widely used. In such operations, the amount of makeup water added is roughly equal to the amount of water evaporated in saturating the flue gas plus the amount entrained or combined with the solid waste produced. The remaining liquor (pond or thickener overflow) is recycled to the prosess. As a result, the chlnride concentration can rise to as much as $5,000-10,000 \mathrm{ppm} ;{ }^{29}$ the net result is an extremely corrosive chloride solution. Chloride bulldup can also cause a decrease in $\mathrm{pH}$ and adversely affect $\mathrm{SO}_{2}$ removal efficiency. Special corrosion-resistant alloys, which can be expensive, are generally required for service in acidic environments that contain chlorides.

\section{Mechanical and Thermal Considerations}

While they are being exposed to extremely aggressive acid-chloride solutions, the materials used in FGD systems can be subjected to several sources of erosion and mechanical loading.30-32 The reactants used to absorb $\mathrm{SO}_{2}$ in 1 ime/limestone and magnesium oxide scrubbing systems are insoluble and are introduced as a slurry containing 5-15\% solids by welght. Erosion-corrosion can therefore be a problem not only in the recirculation pump and scrubbers, but also in equipment for handing the sludge prior to concentration. Erosion-corrosion can also be produced by fly ash or particulates present in the flue gas prior to their removal. The severity of this type of degradation depends on many varlables such as $81 z e$, concentration, and physical properties of solid particles in the gas or 1iquid; Impinging angle of the particles; flow speed; acld content of the medlum; and temperature. In the acid-chloride environment of FGD systems, relatively small mechanical anc thermal stresses can lead to stress-corrosion cracking. Fatigue fallure 18 also encountered in the induced-draft (ID) fans. 
Flue gas leaving the air-preheater section prior to entering the scrubbing system is cooled to $300^{\circ} \mathrm{F}$ or less. However, If there is a plant power fallure, much hotter gas enters the scrubber system. If the pumps providing quench water to the scrubber system are not provided with emergency power, they too become inoperable. This combination results in temperature excursions in excess of $600^{\circ} \mathrm{F}$; under these conditions, organic polymer materials can be destroyed and corrosion in the presence of sulfates and acid chlorides cin become more severe. ${ }^{33}$ Therefore, it is necessary to incorporate alternative safety features in the design of FGD systers or to choose materials that can withstand these temperature excursions.

\section{Current Approaches to Improving FGD Technology}

All of the wet scrubbers described above require waste handling, are susceptible to scaling problems, consume large quantities of water and require corrosion-resistant materlals for construction. To overcome these difilculties, dry-scrubbing processes have been developed.13-15 These processes (Table III) yleld a dry waste, eliminating the need for sludge handling. Also, since these systems do not create a corrosive environment, they can be fabricated with inexpensive materials (e.g., low-carbon steel). Although dry systems are attractive from a materials viewpoint, their use is limited to low-sulfur fuels because their $\mathrm{SO}_{2}$-removal efficlency is lower than that of the wet systems (< $70 \%$ vs $>90 \%$ ). Therefore, the current trend is to update or improve the existing lime/1imestone scrubbers by enhancing $\mathrm{SO}_{2}$-removal efficlency and reducing the amount of sludge produced. 34 This is accomplished by the following methods:

(1) Addition of $\mathrm{Mg}$ (thiosorbic lime) to lime or limestone in the scrubber, which produces $\mathrm{MgSO}_{3}$.

(2) Addition of adiplc acid, which acts as a buffering agent.

(3) Addition of $\mathrm{CaCl}_{2}$ and formic acid, which produce $\mathrm{CaHSO}_{3} \cdot$

(4) Forced oxidation of $\mathrm{CaSO}_{3}$ to gypsim, which reduces the amount of sludge, improves the physical properties for disposal purposes, and also produces a useful bypro iuct.

In all of the above cases, the sclution chemistry is altered. For example, the $\mathrm{MgSO}_{3}$ produced in (1) is nore soluble than $\mathrm{CaSO}_{3}$, and the $\mathrm{CaHSO}_{3}$ produced in (3) Is more soluble than $\mathrm{CaSO}_{3}$. Both of these process alterations allow a higher concentration of sulfite lons and a higher efficiency of sulfur removal. 
IV. SCHEMES FOR SELECTION AND PROTECTION OF WET-SCRUBBER MATERIALS

A. Material Vartables and Experimental Conditions

Extensive repor: 3 have been written ${ }^{35-43}$ concerning corrosion experfence in wet scrubbers, and selection and protection schemes for materials to be used in the highly corrosive scrubber environments. Many of the materials-related problems inftially encountered at several plants clearly stemmed from the improper cholce of structural materials for the FGD component8, which was due in part to the lack of long-term operating experience with a particular material. The materlal degradation observed (pitting, crevice corros'on, stress-corrosion cracking (SCC), general corrosion, and intergranular corrosion, depending on the location) can be related to corrosion caused by acids and chlorides (present in the liquid, solld or gas phase) and erosion due to abrasive particulates and chemicals utilized in the scrubber systems; cyclic or constant stress can also be a contributing factor. In the case of stainless steel, the chloride attack is often augmented by the scale deposition that invariably occurs in wet-scrubber systems; solids deposited on the surface of the steel decrease the local oxygen supply and help to prevent formation of the protective oxide film. Figure 3 schematically 1llustrates vartous types of corroston 44 that are possible in FGD systems. Locallzed attack and fly-ash erosion can occur in spray nozzles where quenching of flue gas takes place. Erosion-corrosion can be a problem with the recirculating pump, while pitting and crevice corrosion can occur in the absorber. Failure of reheater tubes can occur by stress-corrosion cracking. Other areas of concern are dew-point corrosion downstream of the demister and stack, and corrosion-fatigue fallure in the ID fans. While Fig. 3 presents a grossly oversimplified picture of the various types of attack, it shows the complexity of the phenomena and highlights the importance of choosing the appropriate materials for each component of FGD systems.

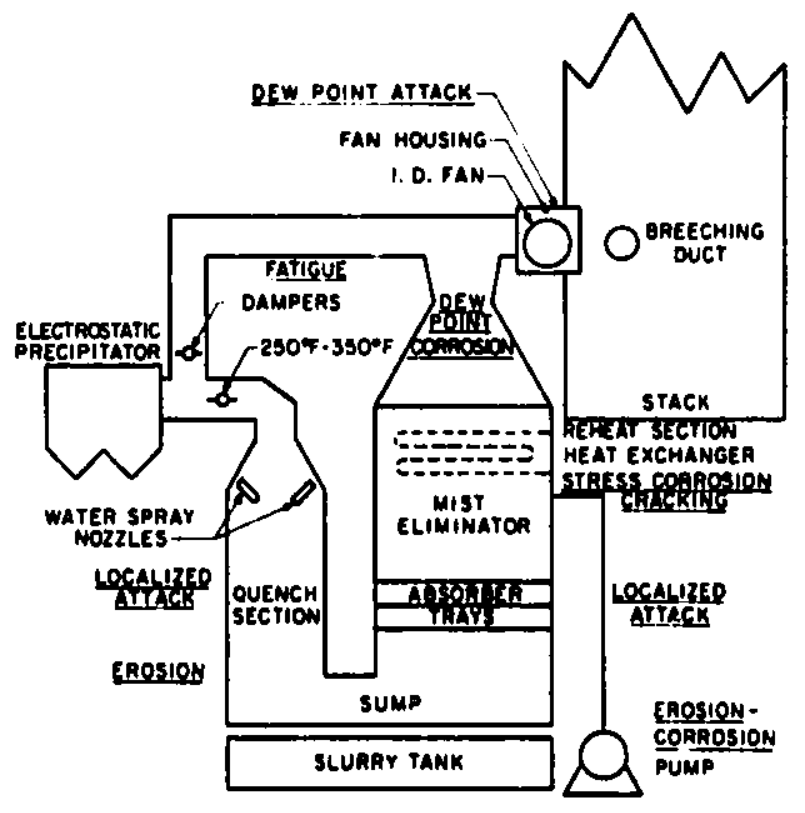

F1g. 3. Wet Scrubbing System, Showing Areas of Possible Corrosive Attack. (Ref. 44) 
Some insight into the judiclous selection of materlals can be obtained from the work of Hoxle and Tuffnell ${ }^{31}$ of International Nickel Co., which is quoted widely in the literature. Their investigations on corrosion of alloys in scrubber environments correlated the extent of localized attack (pitting and crevice corrosion) with (1) chloride-1on concentration and pH of the scrubbing 11 quor and (2) the molybdenum content of the alloy. Figure 4 shows the effect of $\mathrm{pH}$ and chloride content on corrosion of Type 316L stainless steel. The exposure temperatures were generally in the 120$140^{\circ} \mathrm{F}$ range, but a few were as $h 1 g h$ as $277^{\circ} \mathrm{F}$ and one reached $500^{\circ} \mathrm{F}$ during the upset condition. The combinations of $\mathrm{pH}$ and chloride concentration that were tested fell into three regions (severe, sometimes severe, and not severe); severe attack was correlated with low $\mathrm{pH}$ and/or high chloride contert. Simflar results are shown in Fig. 5 for Type 317L stainless steel. The greater resistance of lihe latter alloy to pltting and crevice corrosion has been attributed to higher $M r$ content.31 The importance of Mo in imparting resistance to chloride attack has been demonstrated by several other investizators, 45-49 and is substantiated by the results shown in Fig. 6.31 Recently, Crim et al. 50 have confirmed these results for several alloys in simulated $\mathrm{SO}_{2}$-scrubber environments $\left(\mathrm{SO}_{2}\right.$-saturated solutions containing varying amounts of chlorine). While the latter experfments cannot be directly extrapolated to scrubber environments, they assist in the screening of materials for use in the FGD systems.

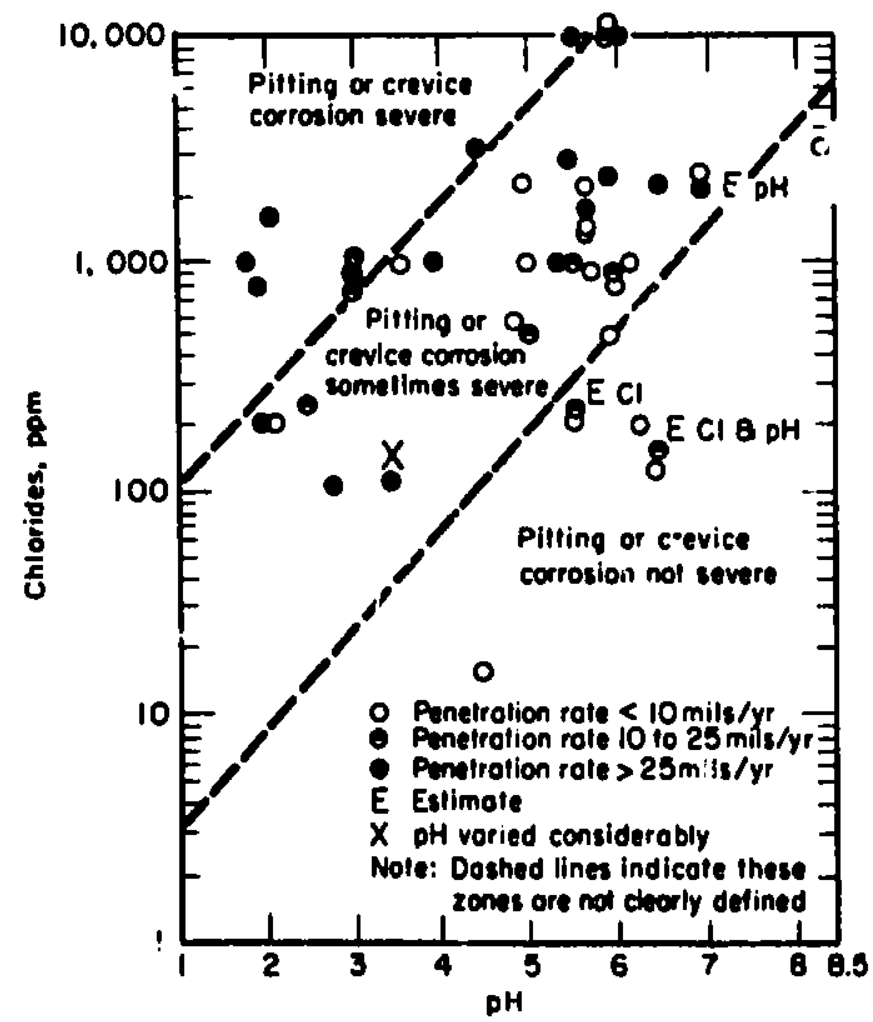

F1g. 4. Effect of Chlorlde Concentration and pH on Rate of Localized Attack on Type 316L Stalnless Steel. (Ref. 31) 


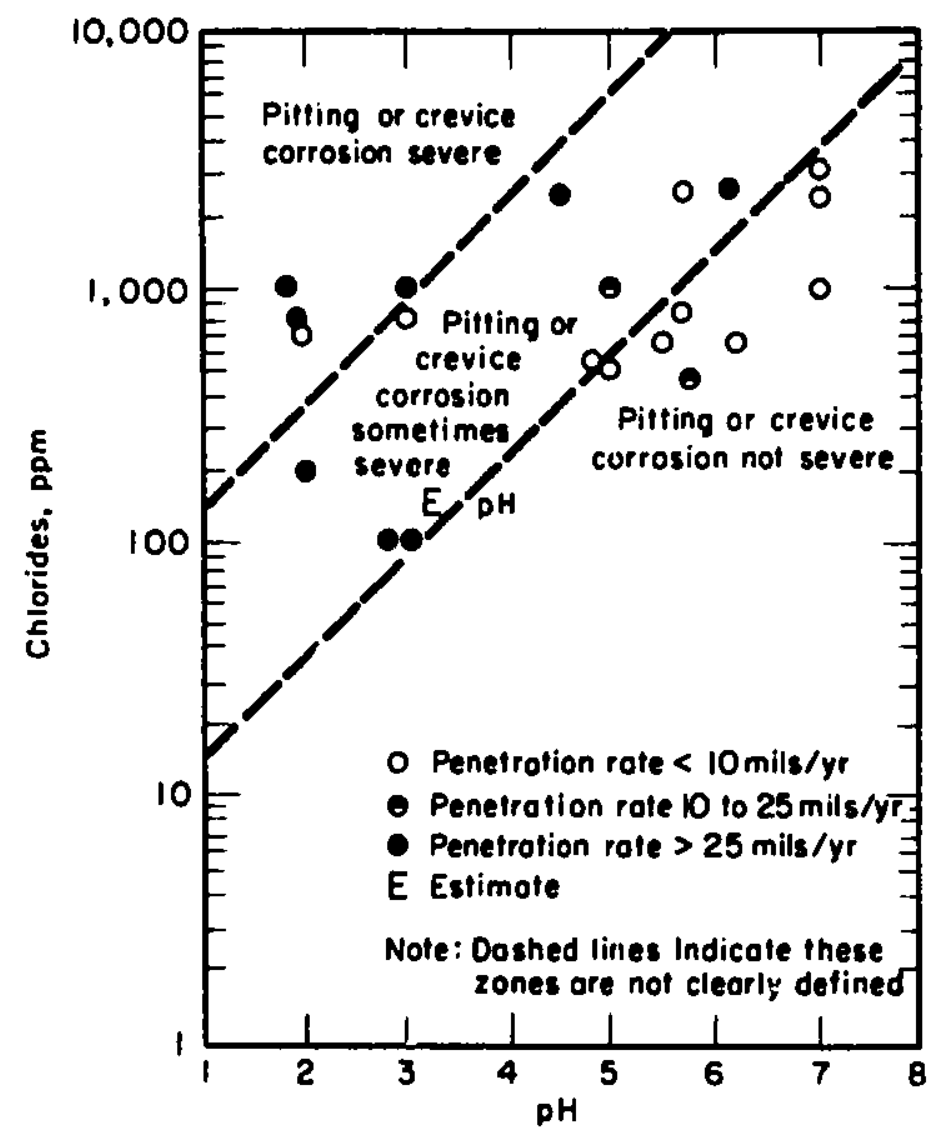

Fig. 5. Effect of Chloride Concentration and pH on Rate of Localized Attack on Type 317L Stainless Steel. (Ref. 31)

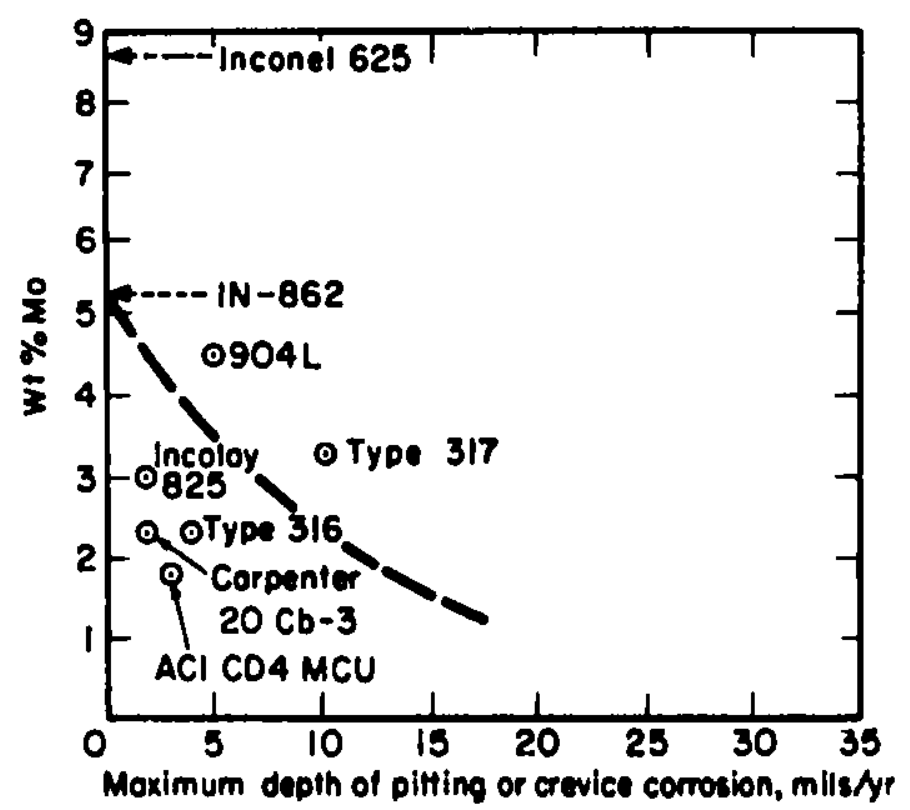

Fig. 6. Effect of Molybdenum Content on Pitting and Crevice Corrosion of Stainless Steels. (Ref. 31) 
The type and extent of attack observed for a given materlal can vary from one location to another in a scrubber assembly. For example, mild steel has experienced severe general corrosion in the inert flue-gas duct; the same materlal has exhibited pitting in the effluent hold tank and has been completely destroyed by erosion-corrosion below the venturi throat. 33

Stress-corrosion cracking (SCC) has been observed ${ }^{35}$ in a section of Type 316L stainless steel inlet duct that extends into the cavity above the venturi, at temperatures of $260-330^{\circ} \mathrm{F}$ and high concentrations (400-8400 ppm) of chloride ion in the process slurry. The residual stresses produced by cold working and welding, as well as the cyclic stresses produced by vibrating equipment, may have contributed to SCC. It is generally known that SCC requires the presence of three factors - surface tensile stress, a susceptible alloy, and a sultable environment. Elimination or alteration of any one of these can prevent attack. In the scrubber environment, SCC can be avoided by proper heat treatment to relleve stresses; however, this is expensf.ve and difficult to carry out for the complete system, and the usual solution is to select special corrosion-resis'ant alloys.

The use of acid-chloride resistant llloys for FGD components can be prohtbitively expensive because of the large number of components affected. Th.1s can be illustrated by considering the scrubber system above the demister, where there is no circulation of the scrubbing liquid. Extensive corrosion, caused by the accumulation of acids and solids, can occur in the demister, induced-draft blades, duct, separator-tower top cone, fan inlet box, reheater tubes, and stacks. In many cases, the first corrosion failure occurs in the region aftor the demister. Fans downstream of the scrubber appear to be particularly prone to corrosion because the heat they generate dries out the scrubbing liquid, allowing acids, chlorides, and other solids to accumulate. In addition, the fan head is subjected to significant rotational and vibrational atress and is hence susceptible to SCC and corrosion fatigue. Type 316L s,cainless steel has a relatively low yield point, thus limiting the fan 11f.time. Mater1als such as Inconel 625 or Hasteiloy $C$ have better mechanical $r$ ioperties as well as corrosion resistance, but are expensive. Stack material 18 subjected to acid and chloride condensates; because of the large amount of material required in the stack, the use of corrosion-resistant alloys 18 very expensive. Thus, other approaches to solving corrosion problems, such as the use of organic and inorganic materials and 1 inings on inexpensive alloys such as mild steel, must be considered. The low-temperature environment prevalent in scrubber systems permits the use of these materials in connecting ducts, scrubber body, fan housings, stacks, and many other FGD components.

As we have discussed, most of the FGD components undergo some form of corrosion, although the severity and form of corrosion can significantly vary from one location to another. The cholce of mater lals of construction (alloys, organic and Inorganic mater1818, 1inings) should be basfd on several environmental factors discussed in previous sections of this repiort, such as composition of the $88 \mathrm{~s}$ streams and scrubber liquor, $\mathrm{pH}$ of influent and effluent 11quor, temperature of scrubbing liquor and exhaust gases, velocity of liquor and gas streams, and abiasiveness of particulates in gas and 11quid. Materlal selection and protection schemes are also affected by cost 
considerations and operating procedures, and can thus vary from one plant to another.

B. Materials Used In Current FGD Systems and The1r Performance

From the preceding discussion, it is clear that no single material seems universally acceptable for $\mathrm{SO}_{2}$ scrubbers from the viewpoints of both performance and cost. Several investigators $35-41$ have discussed the cholce of materials for wet flue-gas scrubbers and experfence related to corrosion and other processes that lead to materials degradation. The most extensive survey of FGD systems and operating experlence with respect to materials performance has been carried out by Rosenberg et al., 22 who reviewed $\sim 40$ systems (see Table IV). Also of great value are the continuing EPA surveys of FGD processes used by utility companies (see, for example, Refs. 51 and 52). These surveys cover operating experiences at existing plants and include flow dlagrams of all operating scrubbers. In addition, information is given on plants under construction, thus providing guidance as to which problems are likely to be most important in the future.

The materlals utilized in FGD systems in operation today fall into three categories: (1) alloys, (2) ceramic and inorganic materials, ard (3) organic materials. Some of the 1mportant alloys of current interest are isted in Table $V$. Depending upon the application, the alloys are elther unprotected or protected with thick organic coatings or ceramic material. The coatings are sometimes Impregnated with alumina to improve abrasion resistance. Organic linings find applications in prescrubbers, absorbers, ducts, stacks and tanks. Iuorganic materlals are sometimes used for prescrubbers, spray nozzles, slurry pumps, outlet ducts, bypass ducts, and stacks. Prefired acid- and wear-resistant bricks, sometimes reinforced with chemically boinded materials (silicon aggregates, sodium silicate, silicon fluoride and colloldal silica bond phase) are used as prescrubber, out let-duct, and stack linings. The following brlef summary of materlals used for FGD components (details can be found in Rif. 2\%) shows the flexibility that exists in the cholce of materials for specific components:

Prescrubbers: These are cliambers through which the flue gas passes with iftele $\mathrm{SO}_{2}$ removal. Because hot erosive conditions prevail, organic coatings or linings on carbon and alloy steels are not very useful unless they are protected with another materlal such as hydraulic or chemically bonded concrete. Alloy steels without linings are also used. Since Types 304 and $316 \mathrm{~L}$ stainless are susceptible to chloride attack, the current trend 18 to choose 317L, Uddelıolm 904, Incoloy 825, or Inconel 625.

Abosrbers: A combination of materlals such as alloy steels, rubber-11ned and other organic-11ned carbon steel, and ceramic-lined carbon steel is used.

Spray Nozzles: Many materials, ranging from plastic (Noryl resin) to extremeily hard alumina $\left(\mathrm{Al}_{2} \mathrm{O}_{3}\right)$ and allicon carbide (SiC), are used.

Mist Eliminatora: All are chevron-type, with a varlety of vane chapes. The rants are made of plaatic, with or without fiberglass reinforcement. Among alloys used for this component, Type 316L atainless steel 18 a comon cholce, although Hactelloy $\mathrm{C}$ is better. 
Table IV. Desertption of FCD Systens visted (RAf. 22)

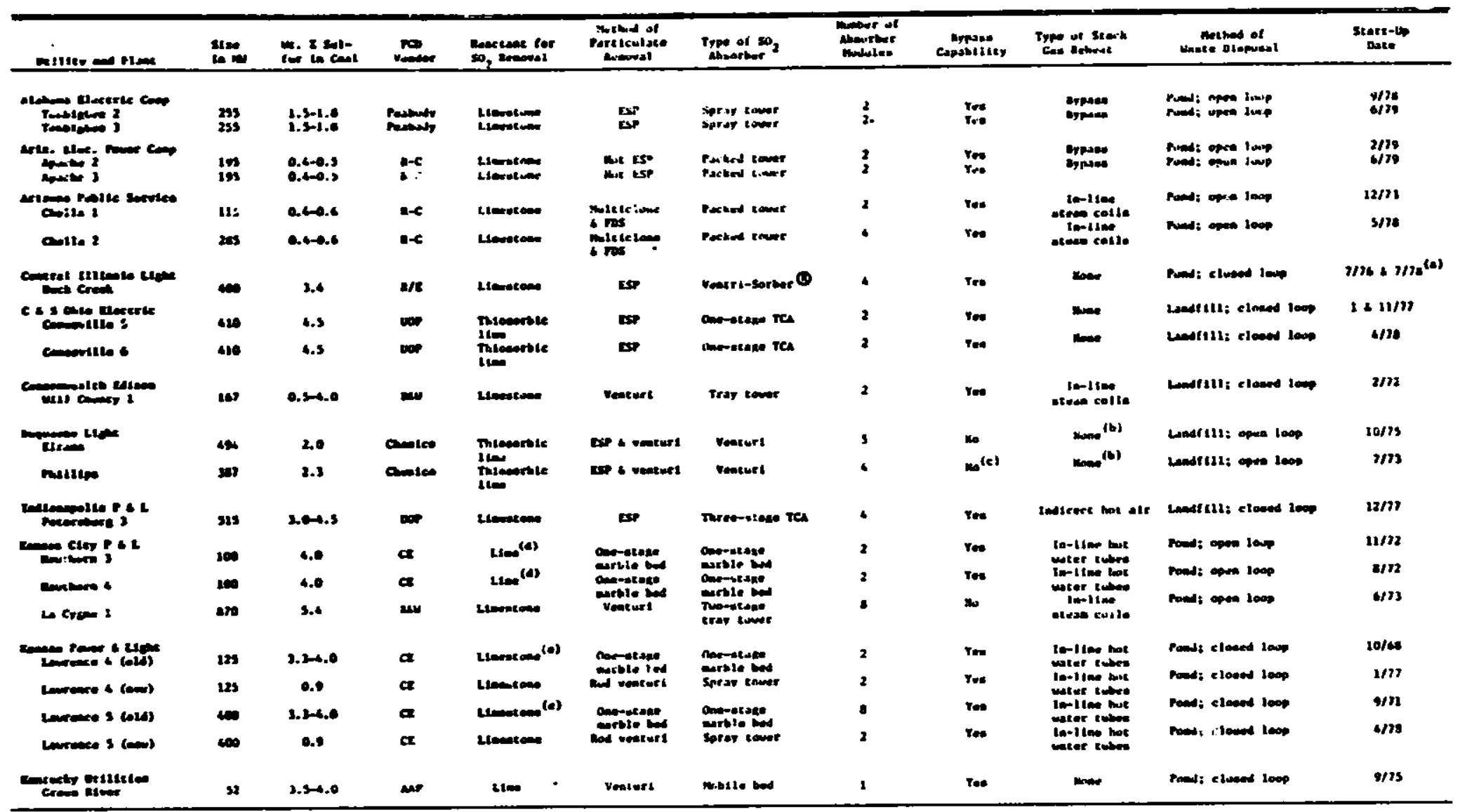


Table IV. (Continued)

\begin{tabular}{|c|c|c|c|c|c|c|c|c|c|c|c|}
\hline matlsy an Ploee & $\begin{array}{ll}81 \times 0 \\
10 m\end{array}$ & $\begin{array}{l}\text { Mh. } x \text { sol- } \\
\text { tur } 10 \text { cosi }\end{array}$ & vencor & 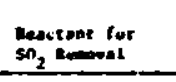 & 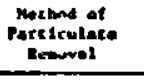 & $\begin{array}{c}\text { Type of } \mathrm{SO}_{2} \\
\text { Abeusbor }\end{array}$ & Metier of & capatilicy & $\begin{array}{l}\text { iype of stack } \\
\text { cate neliese } \\
\end{array}$ & $\begin{array}{l}\text { Muthod of } \\
\text { Warete Diepoest } \\
\end{array}$ & $\begin{array}{c}\text { Setart-vp } \\
\text { setere }\end{array}$ \\
\hline 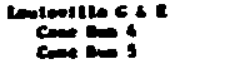 & 200 & 3.: & $\underset{c z}{m}$ & $\begin{array}{l}\text { Carbide } 3100 \\
\text { corbide iter }\end{array}$ & ESP & $\begin{array}{l}\text { Mullie bed } \\
\text { spray tower }\end{array}$ & 2 & You & 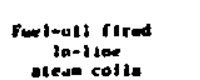 & $\begin{array}{l}\text { Pood: open lwop } \\
\text { Pund: open loop }\end{array}$ & $\begin{array}{l}8 / 76 \\
12 / 77\end{array}$ \\
\hline 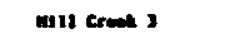 & 423 & 3.॰ & ur & carbide iten & ess & Mel11e ted & 4 & ve. & 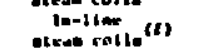 & Pows: upena lows & $m$ \\
\hline 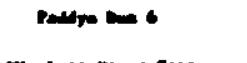 & as & 3.7 & $\boldsymbol{c x}$ & carbide liee & $\mathbf{E s}$ & 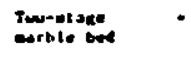 & 2 & rese & 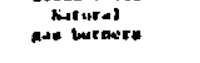 & LondfIII: slosed dnop & $4 / 73$ \\
\hline 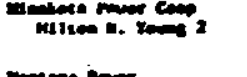 & 40 & 0.7 & cen & Allotion & $\mathbf{E s}$ & Spray smerer & 2 & ree & 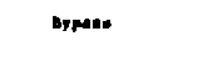 & Lepdtili: eloned loop & $s / 11$ \\
\hline colocterts & 20 & 0.1 & cen & Lter/slks- & veneurt & veacurt and & 3 & mo & 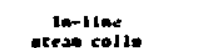 & Pand: cloow toon & t1/7s \\
\hline Colotelp 2 & 200 & 0.7 & cas & 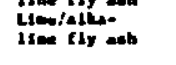 & Vessurf 1 & 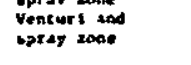 & 3 & mo & 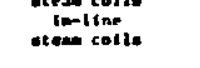 & Fond: cloned 100p & $8 / 16$ \\
\hline 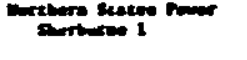 & 220 & $0 . \bullet$ & $\boldsymbol{c x}$ & 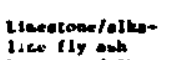 & Deat venturt & $\begin{array}{l}\text { ane-ptape } \\
\text { Wurble bed }\end{array}$ & 12 & mo & $\begin{array}{l}\text { In-11ime hot } \\
\text { water inbat: }\end{array}$ & Puadi open loop & $s / 76$ \\
\hline 2 & 720 & 0.* & ce & 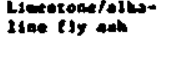 & Rob vematart & $\begin{array}{l}\text { Oeve-ntasee } \\
\text { arble bod }\end{array}$ & 22 & 10 & $\begin{array}{l}\text { Iall me noe } \\
\text { weter eubas }\end{array}$ & Pand: upen Joop & $6 / 77$ \\
\hline I & as & $2.0-3.0$ & antco & $\begin{array}{l}\text { Thiosortile } \\
\text { ita }\end{array}$ & Veacuri & veneurt & " & wo & mone (b) & Puad: upen 1nop & 4776 \\
\hline aruse mofltose 2 & 203 & $2.0-5.0$ & andes & Thionotule & Woeturt & Veaturi & - & $\omega$ & momes & rued: open 100p & $10 / 11$ \\
\hline 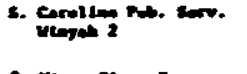 & $200(8)$ & 2.0 & w & Lineercon & Est & $\begin{array}{l}\text { Yencurt to one } \\
\text { etape trat touner }\end{array}$ & 1 & Yee & Bypases (b) & Pond: open loop & $m$ \\
\hline S. & 2000 & 1.6 & I/E & Libectone: & EsP & $\begin{array}{l}\text { Ventrt-Sosber } \\
\text { Ven:ri-Sortert }\end{array}$ & i & Yeat & 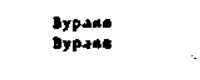 & $\begin{array}{l}\text { Landr(111: cloked loop } \\
\text { Londfilit: sloved loop }\end{array}$ & $\begin{array}{l}9 / 70 \\
6 / 79\end{array}$ \\
\hline 3. Mili & 126 & 23.5 & w & Lientitons & Es: & $\begin{array}{l}\text { Two-stane } \\
\text { iray tower }\end{array}$ & 2 & yee & mone & Lendf1ti: cluend loop & $4 / 79$ \\
\hline 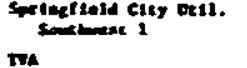 & 196 & $3.5-4.0$ & wor & Lremerose & ESP & Threstarsage TCA & 2 & Yes & None & Landf III: Closed toop & $4 / 7$ \\
\hline 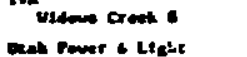 & $3 \times 0$ & 6.0 & Tou & Lienatone & Venturt & Troy turver & ‘ & Yen & Indirect hot afr & Pond: cloced loop & $s / m$ \\
\hline mestimetoos it & 412 & 0.6 & Comico & 210 & ssp & Spray tower & 4 & res & 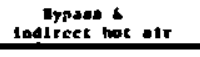 & Londi111: clourd loop & $s / 7 a$ \\
\hline
\end{tabular}


Table V. Major Alloys Currently in Use or Planned for Use in FGD Components

\begin{tabular}{|c|c|c|c|c|c|c|}
\hline & \multicolumn{6}{|c|}{ Typical Composition (wt.\%) } \\
\hline & $\mathrm{Cr}$ & Mo & $\mathrm{N} 1$ & $\mathrm{Fe}$ & $\mathrm{C}$ & Other \\
\hline \multicolumn{7}{|l|}{ Iron-base AZloys } \\
\hline Carbon Steel & - & - & - & Bal & 0.20 (max) & - \\
\hline $317 L$ & 19 & 3.5 & 13 & $\mathrm{Bal}$ & 0.03 & - \\
\hline Uddeholm 904L & 20 & 4.5 & 25 & Bal & 0.02 & - \\
\hline \multicolumn{7}{|c|}{ Nickel-base Alzoys } \\
\hline Inconel $625^{\mathrm{a}}$ & 21.96 & 8.98 & $\mathrm{Bal}$ & 2.97 & 0.06 & $\begin{array}{l}0.17 \mathrm{Mn}, 0.33 \mathrm{Si}, 0.34 \mathrm{Ti}, \\
0.14 \mathrm{~A} 1,0.003 \mathrm{~s}, 0.008 \mathrm{P} \\
3.62 \mathrm{Nb}+\mathrm{Ta}\end{array}$ \\
\hline
\end{tabular}

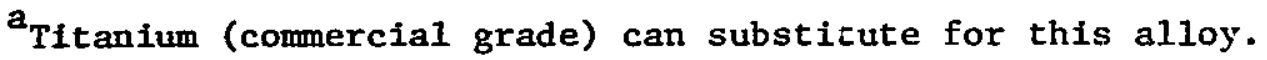


Reheaters: Materials of construction range from carbon steel to Inconel 625 and Incoloy 825 alloys. For low-sulfur coal, Type 316L stainless steel can also be used. Fan housings are rubber lined.

Ducts: Inlet ducts are made from carbon steel or Cor-Ten steel, with Type 316L stainless steel used for some parts. Outlet-duct materlals range from unlined carbon steel to Hastelloy $G$ and Inconel 625 . In wet outlet-duct sections, organic linings (comnonly polyester or epoxy with flake reinforcement) are used to protect the carlon steel structure.

Expansion Joints: The expansion joints in the scrubber system are made of an elastomer with fabric. Fiberglass, asbestos, and metal expansion joints are ilso in use.

Dampers: Inlet dampers use unlined carbon steel; the damper seals are made of alloys such as Type 316L or 317L stainless steel, Hastelloy G, or Inconel 625. The current trend is to replace $316 \mathrm{~L}$ by Uddeholm $904 \mathrm{~L}$ frame, Inconel 625 seals, and Hastelloy C fasteners.

Stacks: Acld-resistant brick, Inorganic and hydraulic cement-bonded concrete, and fluoroelastomer linings have replaced organic linings. Highnickel alloys are being considered.

Storage Silos: Unlined carbon steel is satisfactory, as it is exposed only to alkaline conditions.

Grinding Mills or Slakers: Carbon steel with or without Ni-hard and rubber 1inings is used.

Pumps: Pumps are fabricated from carbon steel (lined or unlined). The Iining, if used, is usually of rubber. Problems with unlined Carpenter 20 steel pumps have been solved by using impellers fabricated of $317 \mathrm{~L}, \mathrm{~T} 1$, and Fe-20\%Cr alloys. Silicon carbide wear plates, epoxy bonded to steel, are used for housings.

Plpings and Valves: Rubber-11ned carbon steel, fiberglass-reinforced plastic (FRP), and Types $316 \mathrm{~L}$ and $317 \mathrm{~L}$ stainless steel alloys are commonly used.

Tanks: Unlined carbon, concrete, FRP, 316L, and carbon steel with some form of glass flake-filled polyester lining are ut1lized in the construction of tanks.

Agitators and Rakes: Blades are constructed of rubber-clad carbon steel, and shafts of stainless steel and unlined carbon steel.

Vacuum Filters and Centrifuges: The vacuum filters and centrifuges used for sludge dewatering are made of carbon steel with or without organic linings, and the filter cloth is prepared from elther polypropylene or nylon.

From the above description of the materials for che FGD components, It is clear that there is a great deal of cholce and flexibility with regard to the materials of construction. Hence, it is no surprise that satisfactory 
operation for as long as 2-8 years has been reported 22 for a few of the FGD components. The operating experience varies from plant to plant; however, an assessment ${ }^{22}$ of the materials problems encountered ir. a number of FGD systems shows that most of the components have a history of materlals problems ranging from minor to significant and prolonged. In general, the materials performance in the existing plants has been better for the components located within the scrubber than for the components located downstream of the scrubber. Because of the varying experience and the uncertainty in the characterfizatiun of environments, it is not possible to establish the statistical significance of fallures. Also, for many of the materials of current interest in FGD systems, particularly organic liners for carbon steel components and organic and inorganic liners (brlaks, refractorles, fiberreinforced plastic, etc.) foi stacks, performance limits have not been established.

Also, a closer examination of Table IV and Fig. 7 shows that the experlence for the larger (> 400-MW) FGD systems which employ closed-10op operations, where higher concentrations of chloride can occur with time, is rather limited (shaded area in Fig. 7). Although Incoloy 825 and Inconel 625 have shown better corrosion resistance than austenitic stainless steels In $\mathrm{SO}_{2}$-scrubbing environments, some corrosion has occurred (Figs. 8 and 9), which can be significant over the anticipated 30-year 1ife span of the FGD systems. The data 53 in Figs. 8 and 9 , which were collected from thirty different plant locations that included utilities, industrial power plants, and copper smelters, also show that Inconel 625 is superfor to Incoloy 825 in FGD environments. Unfortunately, the use of these alloys in bulk quantities for $\mathrm{SO}_{2}$-removal systems is expensive, and their performance over longer periods of time ( $>5$ years) remains to be demonstrated. These considerations of cost and unknown long-term performance may lead to a search for alternate materials based on experience and research studies.

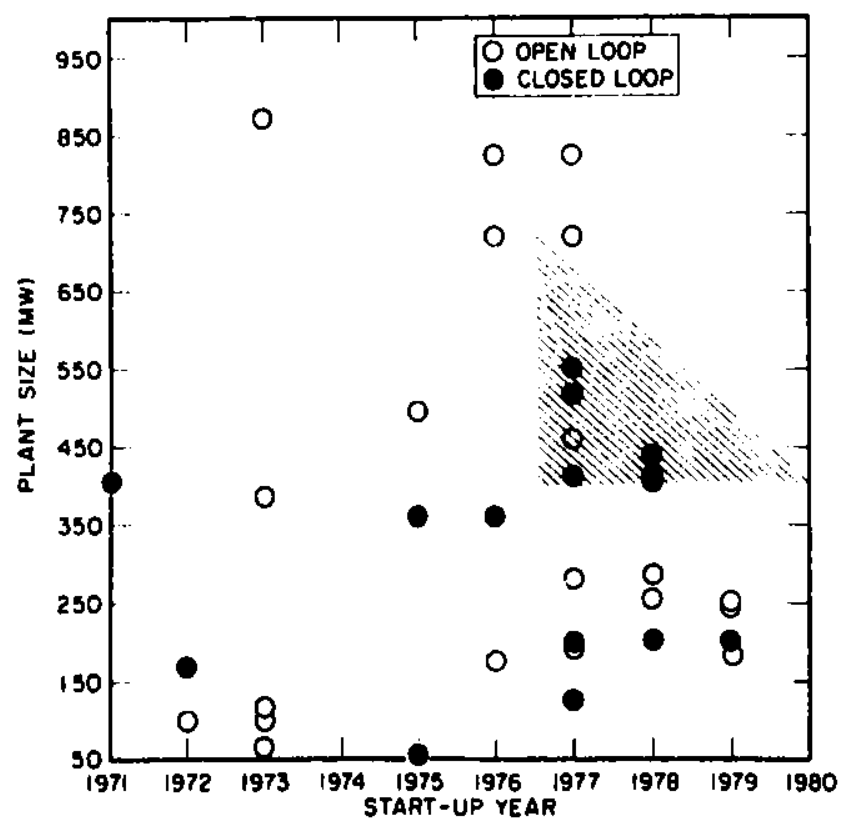

Fig. 7. Wet Scrubbers for WhIch Operating Experfence is Available. 


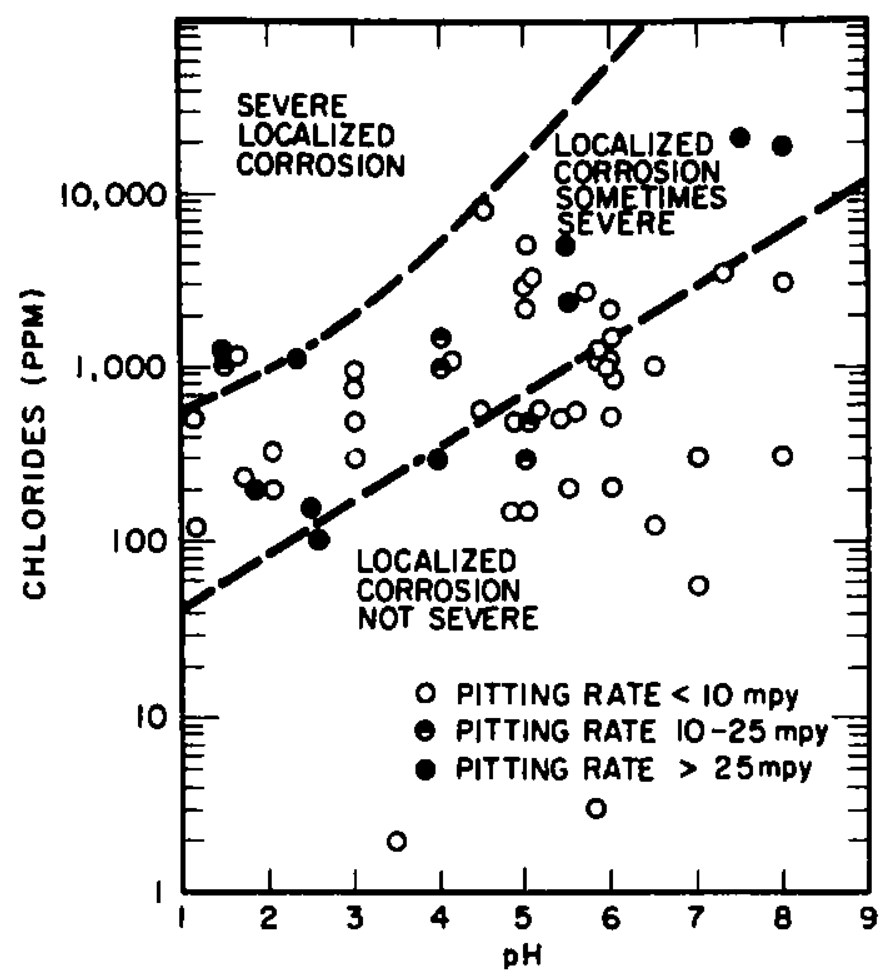

Fig. 8. Effect of Chloride Concentration and pH on Pitting Rate of Incoloy 825. (Ref. 53)

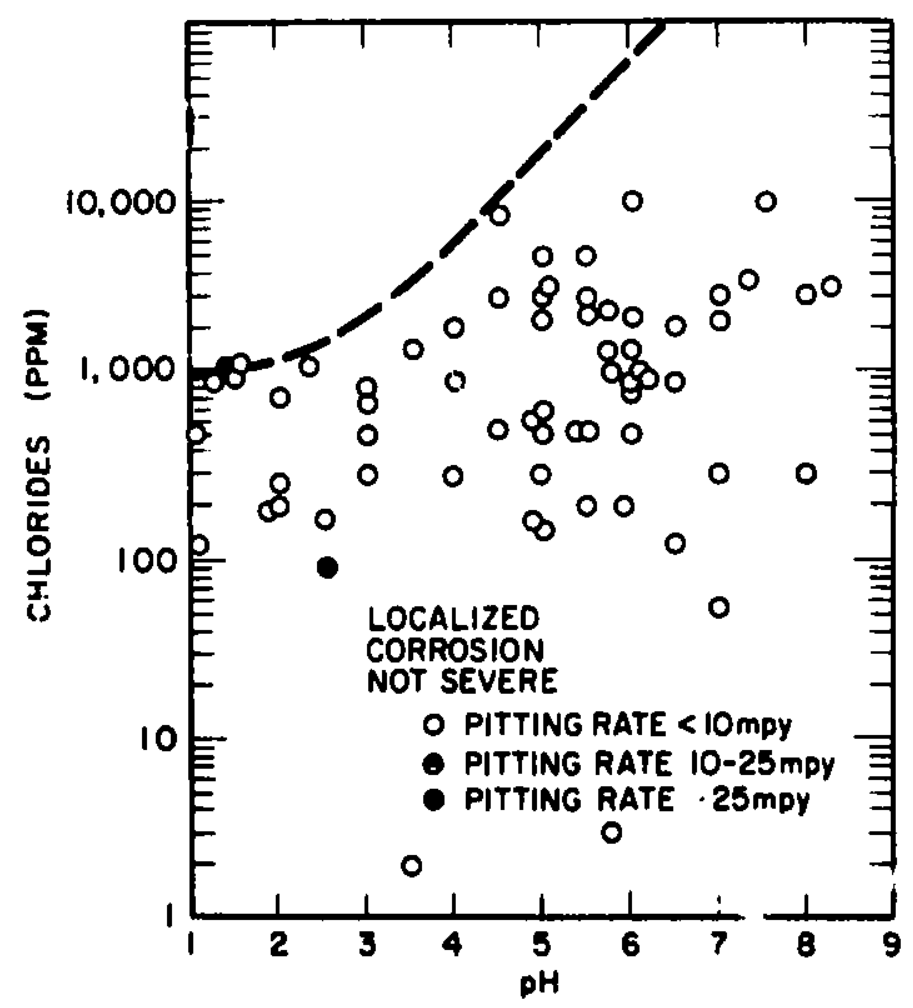

Fig. 9. Effect of Chloride Concentration and pH on Pitting Rate of Inconel 625. (Ref. 53) 
For the Installation of future 11me/11mestone systems, a better selection of materlals may become possible. However, this alone will not solve such problems as sludge disposal, which has been described elsewhere. 54 For example, for a 500-MW boller plant burning 3\%-8ulfur coal, 500,000 tons/yr of sludge will be generated at $50 \%$ solids. The sludge consists primartly of $\mathrm{CaSO}_{3} \cdot \frac{1}{2} \mathrm{H}_{2} \mathrm{O}, \mathrm{CaSO}_{4} \cdot 2 \mathrm{H}_{2} \mathrm{O}, \mathrm{CaCO}_{3}$ or $\mathrm{Ca}(\mathrm{OH})_{2}$, and $\mathrm{fly}$ ash. It is thixotropic and has the consistency of toothpaste or heavy mud. The usual method of disposal, to a pond situated at or adjacent to the plant site, requires many acres of land which will eventually become filled. To deal with this land wastage problem, chemical fixation processes are being developed whereby the sludge is converted to a solid product which is either usable or easily disposed of. As a result of dewatering of the sludge, chloride butldup in the scrubber system will further enhance the susceptibility to corrosion unless approprlate measures are taken in the selection of materials.

\section{SUMMARY AND CONCLUSIONS}

The chemistry and parameters of the flue-gas desulfurization (FGD) process are discussed for IIme/1imestone and other scrubber systems. The environments to which the structural materials are exposed are characterfzed In terms of varlables pertinent to process chemistry, such as $\mathrm{pH}$ and chloride content, as well as mechanical and thermal variables. Even under normal operating conditions, the environments are highly corrostve. In systems involving closed-loop operations, the chloride concentrations in the water may exceed $10,000 \mathrm{ppm}$ and thus the environment continually becomes more corrosive. Consequently, FGD systems require either corrosion-resistant materials (e.g., Inconel 625, Incoloy 825), which are normally used for high-temperature applications, or less expensive materials such as carbon steel with organic coatings (e.g., rubber linings, epoxy). The use of conventional alloys and the selection of alternate materials (alloys, ceramics, other inroganic and organic materials) for the FGD components are briefly described in this report. A critical evaluation of the materials currently In use for many FGD components (mostly those of 11 me/11mestone systems), as judged from their performance over a perlod as long as 2-8 years, shows that materials problems vary from one FGD plant to another and from one location to another within an FGD plant. Materlals research should be conducted for components that have a signifirant and prolonged history of materlals problems and that force a plant shutdown when they fall. In general, the materials problems relative to corrosion appear to be more pronounced and critical for components located downstream of the scrubber than within the scrubber. In light of these existing problems, it 18 important to caintne areas where research and evaluation could significantly contribute to the proper selection of materlals. 


\section{RECOMMENDATIONS}

The utilfty companies and other private industries that burn coal have faced considerable economic penalties in installing FGD scrubbing systems to meet the EPA emission standards. In fact, the costs of flue-gas scrubbers are estimated to be $25-30 \%$ of the total fossil utility plant investment. This cost may run even higher if more stringent controls are placed on air pollution in the future. It is also clear that many components of the existing FGD systems (e.g., stack linings, ducts, bypassduct functions, and reheaters) have a history of materials-rnlated failures, many of which require complete shutdown of the plant. Therefore, materials selection is becoming increasingly important as financial pressures are felt by the utility companies. Proper selection of materials of construction through an appropriate research and development plan can be expected to have great economic impact on current FGD technology. It is a vital aspect in both the design of new FGD facilities and the improvement of existing facilities. It is recommended that a program be undertaken which emphasizes (a) fallure analysis of FGD components and (b) materials research and evaluation by means of both controlled laboratory tests and field studies.

\section{A. Fallure Analysis}

The continuing EPA surveys of utility companies with existing FGD installations include detailed records on operating experience at these plants. Although useful, this alone is not sufficient to alleviate the problems that are encountered, as the environments in which fallures are occurring are not well characterized in many cases. A rigorous analysis of fallures occurring in various FGD environments should be undertaken to establish the environmental and statistical significance of fallures and, wherever possible, to correlate fallures with the service environment. This is necessary to Identify the areas of materials research that will have the greatest potential economic impact on the plant. It is important to establish whether the fallures are site-specific, e.g., related to the coal, water, or chemicals used in the process, or assoclated with an improper cholce of materlals or with a design variable.

\section{B. Research on Materials}

As discussed in this report, the avallable data on performance of materials in various FGD systems have provided some direction for future efforts. It has been clearly demonstrated that neither austenitic stainless steel nor uncoated carbon steel meets the criterla of long $11 \mathrm{fe}$ and troublefree service with a minimum of expensive maintenance requirements. More corrosion-resistant alloys, ouch as Inconel 625 and Incoloy 825, have demonstrated better performance, although their long-term ( $>5 \mathrm{yr}$ ) reliability in service remains to be seen. Materials research on these alloys would be useful, but more economic benefit would be realized if less expensive alloys such as carbon steel, coated with one of these corrosion-resistant alloys or with organic materials, could be substituted. A number of new coating procedures almed at cost savinge are currently avallable, and the applicability of this technology to FGD environments should be investigated. The substitut1on of other, less expensive, corrosion-resistant h1gh-grade metal systems and alloys (e.8., T1) should also be explored. In sumary, future studles 
In the following materlals areas would be of interest and value from an economic viewpoint:

(I) Organic coatings on Inexpensive alloys such as carbon steel.

(2) Coatings of (expensive) corrosion-resistant alloys, such as Inconel 625 , on inexpensive alloys.

(3) F1ber-reinforced plastics and/or refractory materials for stack linings.

(4) Less expensive, corrosion-resistant high-grade metal systems (e.g., T1) and alloys.

(5) Inexpensive alloys for which surface compositions can be modified to enhance their corrosion resistance in FGD environments.

\section{Controlled Laboratory Experiments}

The erosion-corrosion problems encountered in FGD environments are varied in nature and depend on a large number of factors; in many cases, FGD processes are not well characterized in terms of the environmental variables (e.g., pH, chloride content). Therefore laboratory experiments alone may prove insufficient to predict matertal behavior. However, laboratory studies are Invaluable in narrowing the list of candidate materlals that need to be tested under actual operating conditions.

110ys 50 Laboratory experiments similar to those already done on high-nickel alloys and stainless steels are needed to evaluate the effects of variables such as $\mathrm{pH}$, chloride content, and temperature on coated and uncoased mater. loss (corrosion rate), pitting rate, and type of attack. But organic coatings do not exhlbit the same responses as metals in corrosive service. The dimenstons of these coatings are rarely changed by exposure to corrosive media; rather, the effect of the FGD environment, if any, may be to alter the structure of the coatings at varying rates. This can lead to decohesion and eventual mechanical fallure of the coating material. Thus, study of the rates at which coating properties change should shed light on the reliability of the materfal. The abrasive resistance of some of the coatings on steels can he determined in accordance with ASTM standards. It is also necessary to develop testing methods to evaluate the mechanical and thermal stability of stack linings prior to application.

\section{In-service Testing}

Since the types of corrosion fallures observed in FGD systems are numerous, it is important to investigate a variety of different types of fallures, such as crevice corrosion and susceptibility to SCC, in material systems being considered for FGD applications. In-service testing using small specimens and actual or simulated components is extremely important to 
characterize the synergistic effects of chemical and design variables as well as to test the validity of FGD design practice. The fleld tests should be carried out in the best-characterfzed FGD environments. Post-testing of materials is an important part of the proposed program, as it helps to Identify the fallure mechanisms, performance limitations and potential problem areas.

\section{MATERIALS PROGRAM FOR LIME/LIMESTONE SCRUBBER COMPONENTS}

A. Scope

The proposed Argonne National Laboratory (ANL) program will provide materials support for wet scrubbers with particular emphasis on lime/limestone scrubber technology. The objective of the program is to evaluate materials capability for existing scrubbers as well as gulde materials selection for future processes and developments. The overall program comprises three subtasks:

\section{(1) Failure analysts of field componen' i. \\ (2) Materials testing and evaluation. \\ (3) Analysis and recommendations.}

Comprehensive failure analyses are needed to identify the underlying mechanlsms of actual field failures. The results will have an imediate impact on the repalr and rellable operation of scrubber systems, and will provide guldance for the selection of materials for additional testing and evaluation. Systematic laboratory and fleld testing are needed to develop adequate information for the selection and development of improved materials. In addition to the data obtained, the impact on the overall process economics and reliabllity will be taken into account in making specific recommendations concerning materials selection. The results will be documented in the form of quarterly reports and an inter $\mathrm{Im}$ report at the end of each year; a final report will be issued on completion of the program.

Based on our evaluation of materlals performance in existing lime/ limestone scrubbers, we have chosen to concentrate on problems related to critical components, namely stacks, ducts (downstream), and reheaters. However, in the future, if critical problems develop in other components (e.g., erosion in ID fans) as a result of continued operation of the existing plants and process developments, we will redirect the program accordingly.

Throughout this program, close contact will be maintained with the utflity companies and equipment manufacturing companies so that the information generated by the program can be made avallable to guide decisions on repalr or replacement of scrubber components, Improved operation of existing plants, and materials selection in the construction of new scrubbers. 
The scope of the proposed program must, of course, be compatible with the available funding. The test variables involved are complex and the materials utilized in the scrubbers are numerous, ranging from plastic to Iron- and nickel-base alloys. The proposed program includes fleld tests on specimens in service and removal of the specimens for evaluation at specifled intervals. Tests made under actual operating conditions in plants can be expected to provide reliable guidelines for the selection of materials to be used under similar conditions. These tests may be supported by supplementary tests using controlled conditions.

For the first year, the proposed budget is about $\$ 250 \mathrm{~K}$, which is expected to fund 1 staff member, 1.5 support personne1, and capital equipment including environmental chambers. In the first year, our efforts will be directed primarily toward the development of testing facilities, specimen design and preparation, and interaction with the utflity companies concerning field tests and failure analysis. Further development of testing capabilities will be required as the program continues. Some exploratory and feasibility experfments will be performed as testing equipment becomes avallable. We recommend that the program be expanded after the first year to provide 1 staff member and 1.5 support personnel for the materials evaluation program (which includes both laboratory and fleld experinents) and additional staff and support personnel (0.5 man-year each) to perform fallure analyses and other tasks. Since the current investment in scrubbers forms a significant fraction of the total plant cost and the availability and rellability of existing scrubbers (especially those associated with high-sulfur coal) are unsatisfactory, we believe that the proposed materials program is the minimum necessary to provide adequate materlals support for scrubber technology.

\section{B. Proposed Program}

\section{Failure Analysis of Field Components}

Fallure analysis is an important part of the materlals program. It provides information on materlal performance under actual operating conditions. The results will have an immedlate 1mpact on the repalr and reliable operation of scrubber systems. Furthernore, they will provide valuable 1nformation and guldance for the materials evaliacion program as well as for the selection and development of materlals for future plants.

It is not feasible or informative to investigate all the fallures encountered in the scrubber assemblies, and therefore, we propose to focus primarily on those fallures which result in a complete plant shutdown, e.g., fallure of stacks or downstream ducts. In addition to these critical components, reheaters and fans represent particularly trouble-prone components where further materials development and improvement can be beneficial, and therefore will be included in the program. To determine the fallure cases to be examined, it is necessary to work closely with the utility companies and to ut1lize other sources of information such as the EPA ut1lity FGD survey. A fallure analysis will generally begin with plant trips to acquire detalled information concerning the design, fabrication, and service history of the failed components and to select components for detailed investigation. A coinplete aralysts could involve, for example, metallographic and other microstructural examinations; the use of other analytical tools, such as 
$x$-ray spectroscopy; mechanical testing; and thermal and stress analysis. If necessary, the expertise of other ANL staff in the areas of general corrosion, intergranular corrosion, stress-corrosion cracking, and corrosion fatigue is avallable on a case-by-case basis. We will also interact with utility companies to take advantage of their experience and to confirm our findings. A detailed report of our findings will be 1ssued together with our recommendations for future action. The ANL effect will be coordinated with that of other DOE contractors to avoid duplication.

\section{Materials Testing and Evaluation}

The materials evaluation program w 111 be coordinated with the fallure analysis efforts, and therefore, it will primarily be concerned with the same components, namely stacks, downstream ducts, reheaters, and fans. At present, these components are fabricated from a varlety of materlals, as discussed in Chapter IV of this report. Therefore, a judiclous choice of materials to be tested is important to insure the development of a meaningful program. The initial selection of materials for the proposed program is based on the available experience relited to materlals performance of wet scrubbers, as discussed in this report, and includes considuration of process modiffcations and requirements for future processes.

During service, materials in the scrubber will experience a combination of complex chemical, thermal, and stress environments. For example, in reheaters, residual stresses exist in the welds and thermal stresses are produced as a result of fluctuations in temperature of the steam, hot water, and flue gas. Acld and chloride condensates on the surfaces of various components produce aggressive chemical environments. The chemical composition of these deposits can vary as a function of time ill a plant, depending on the operating conditions and the impurity content of the coal, water, and lime/11mestone utilized in the process. Particularly for the scrubbers that operate in a closed-loop mode, the amount of chloride bulldup increases with time, producing a continuously changing corrosive environment. In addition, the scrubber components (e.g., ducts and stacks) experfence alternate perfods of "dry" and "wet" conditions in conjunction with temperature fluctuations.

It is well known 55 that the rate of degradation of materials is more rapid under cyclic conditions than under conditions of exposure in a steadystate situation. The material degradation is augmented by cyclic loading and temperature cycling, and furthermore, the existence of cyclic "dry" and "wet" states resuits in the enhancement of corrosion rates. Therefore, the effects of cyclic environmental variables on the degradation rate of scrubber materials must be emphasized in the proposed program. It is also posisible that combinations of more than one type of cyclic effect may exist, depending on the system. It should be recognized that it is difficult to define "typical" operating conditions for the existing plants, which undergo frequent and lengthy shutdowns, such that environmental variables are not well characterized. Hence, it is essential to develop a program that includes both laboratory and field experiments. 
The proposed program includes laboratory corrosion tests under dynamic conditions and under a combination of one or more environmental cycling variables (e.g., temperature, pH, stress, and chlorine), and corrosion fatigue tests. Because tests under cyclic conditions are more difficult and expensive, simpler tests with constant environments and constant mechanical loads will be used first as screening tests to 1dentify the most promising materials for more comprehensive testing. Thus, the testing program will include three general types of laboratory experiments:

(a) Laboratory exposure under steady-state conditions with controlled temperature, chemlstry, and stress. For metallic specimens, the depth of corrosive attack and related microstructural changes and the number, depth, and distribution of pits, cracks, etc. will be examined: For nonmetallic specimens, visual and microstructural examinations will be made and the dimensional changes, elastic modulus, strength, hardness, and other varlable properties determined.

(b) Laboratory exposure under cyclic environmental condit lons. In this type of experiment, the chemistry and temperature of the corrosive environments are controlled such that the specimen is subjected to cycling of temperature and/or chemical environment ut various frequencies. After the exposure, specimins are examined in the same fashion as in (a) to determine the extent of degradation Involv'sd. Other experiments will involve cycling between "iry" and "wet" conditions, which 1s expected to be espectally important for plastics.

(c) Stress and strain cycling of specimens in corrosive environments. A 1 imited number of fatigue tests under controlled temperature and chemical environments will be performed to evaluate the materlal response to cyclic stress or strain cycles. Corrosion fatigue tests, while recognized as important for metals, have not been widely used for plastics. Both post3xposure and in-situ experiments will be considered. Thus, these experiments, In addition to providing a design data base for the materials, are expected to $d$ velop into a standard testing procedure for evaluating the response of mater als to the hostile environments of scrubber systems. Changes in flexural modulus and strength have been the princlpal parameters used to date for estimating the degradation of the chemical resistance of plastics in a corrosive environment. It is hoped that corrosion fatigue tests under more realistic testing condtions will provide additional quantitative information to supplement the present practice. The methods of corrosion data correlation are well established for metallic materials and the test iesults will be applicable to stacks, ducts, reheaters, and ID fans. The data obtained will be in the form of cycles to fallure or crack 1nitiation and growth rates as a function of temperature, stress, and chemical environments.

In the fleıd experiments, specimens will be exposed to corrosive environments at critical locations in the outlet ducts, reheater, and stacks to simulate the response of components to scrubber environments. The specimens will be removed after varlous exposure t1mes and the extent of material degradation evaluated in a manner similar to that used for the laboratory specimens. 
The plan outlined in Table VI shows the number of specimens that can be tested over a flve-year period based on the proposed funding level. For a speciflc material such as FRP, approximetely 10 specimens can be tested and examined per year for a given set of experimental conditions. To 1llustrate the extent to which the range of test varlables and materials can be investigated, we consider 5 cycling parameters of interest (narrow and broad temperature ranges, stress range, $\mathrm{pH}$ range, and chlorine range) and 4 noncycling steady-8tate varlables (temperature, $72-350^{\circ} \mathrm{F} ; \mathrm{pH}, 1-6$; chlorine, $10^{2}-10^{5} \mathrm{ppm}$; and stress) in the materials evaluation program. For a given materlal, the number of tests needed to assess all the above varlables is 280. Thus, we w1ll be able to examine on $\perp y$ a limited number of materlals, e.g., one metallic system, one FRP, and one lined or coated material.

Careful consideration will be given to the results of the initial screening tests and prior fleld experience before the materials for more intensive testing are selected. The screening tests will also be used to rank the test variables and estimate their importance. However, even if only half of the varlables 1isted above prove to be important, the capability for in-depth Investigation still appears to be limited to only a few materials.

\section{Analysis and Recommendations}

As pointed out earlier in this chapter, our recommendations on the materials evaluation and performance limits will be documented in an interim report at the end of each year along with a final report after the completion of the program. The recommendations will be based on the findings of our laboratory and fleld studies, Information avallable in the 1iterature, and the results of uther DOE contractors. In the analysis, data on materials propertles as well as evaluation of present and future processing variables and economic factors will be considered so as to optimize the materials selection and maximize the performance of the scrubber systems. Throughout the program, we propose to interface with utility companies and other DOF. contractors so that we can share our findings and experience. This type of interaction is espectally important in the decision-making process concerning repairs, replacement and construction of scrubber systems, and also in the screening of materials of construction for the systems. It 18 recognized that many of the materials of construction for scrubbers, particularly coatings, may vary in quality from one manufacturer to another depending on the method of application and surface preparation. It is therefore important to develop a useful and efficient quality assurance program to ensure successful field performence. The proposed ANL program w1ll provide information needed to establish the required test procedures for materlals prior to their use in scrubbers. 
Table VI. Approximate Yumber of Laboratory and Field Tests That Can Be Performed on Va:lous Materials Over a Five-vear Period with the Assumed Man-Year Support Level

\begin{tabular}{|c|c|c|c|c|c|c|}
\hline \multirow{2}{*}{$\begin{array}{l}\text { Material } \\
\text { Relevant Componeats }\end{array}$} & \multirow{2}{*}{ Type of Test } & \multicolumn{5}{|c|}{ Yeбt } \\
\hline & & 1 & 2 & 3 & 4 & 5 \\
\hline \multirow{4}{*}{$\begin{array}{l}\text { Metall ic Systen } \\
\text { (e.k.. Inconel 625) } \\
\text { deheater }\end{array}$} & $\begin{array}{l}\text { Corrosion in flowing } \\
\text { l1quid }\end{array}$ & $5(10)^{b}$ & 10 & 10 & 10 & 10 \\
\hline & $\begin{array}{l}\text { Teaperature/environmental } \\
\text { variable cycling }\end{array}$ & 2 & 10 & 10 & 10 & 10 \\
\hline & Corrosion fat igue & & $<5$ & $<5$ & $<5$ & $<5$ \\
\hline & Field test & $\begin{array}{l}\text { Spec1nen preparation } \\
\text { and installation }\end{array}$ & 10 & 10 & 10 & 10 \\
\hline $\begin{array}{l}\text { Metallic Syster } \\
\text { (e.g.: T1, ferrit1c } \\
\text { steels) } \\
\text { Duct and stack }\end{array}$ & Field test & $\begin{array}{l}\text { Specimen preparation } \\
\text { and installat ion }\end{array}$ & 10 & 10 & 10 & 10 \\
\hline \multirow[t]{4}{*}{$\begin{array}{l}\text { Plactic (e-8., FRP) } \\
\text { Duct and atack }\end{array}$} & $\begin{array}{l}\text { Corrosion in flowing } \\
\text { Ifquid }\end{array}$ & $5(10)$ & 10 & 10 & 10 & 10 \\
\hline & $\begin{array}{l}\text { Temperature/enviromental } \\
\text { cycling }\end{array}$ & 2 & 10 & 10 & 10 & 10 \\
\hline & Corrosion fatigue & & $<5$ & $<5$ & $<5$ & $<5$ \\
\hline & Fleld cest & $\begin{array}{l}\text { Spectaen preparation } \\
\text { and installation }\end{array}$ & 10 & 10 & 10 & 10 \\
\hline \multirow{4}{*}{$\begin{array}{l}\text { Linings ior carbon } \\
\text { steel (e.g., rubber, } \\
\text { epory, FRP) } \\
\text { Duct and stack }\end{array}$} & $\begin{array}{l}\text { Corrosion in flowing } \\
\text { liquid }\end{array}$ & $5(10)$ & 10 & 10 & 10 & 10 \\
\hline & $\begin{array}{l}\text { Temprature/enviromental } \\
\text { cycling }\end{array}$ & 2 & 10 & 10 & 10 & 10 \\
\hline & Corrosion fatigue & & $<5$ & $<5$ & $<5$ & $<5$ \\
\hline & Fleld test & $\begin{array}{l}\text { Spec imen preparai ion } \\
\text { and installation }\end{array}$ & 10 & !n & 10 & 10 \\
\hline
\end{tabular}

a. 1.5 staff +2 support personnel after the first year.

bumbers In ( ) Indicate screening tests in addition to exploratory tests. 
ACKNOWLEDGMENTS

I am particularly grateful to S. Greenberg (ANL) for helpful discussions and invaluable assistance in surveying the literature and preparing the bibllography. W. J. Shack, R. W. Weeks, W. A. Ellingson, and K. Natesan (ANL) provided helpful comments on the manuscript. Technical discussions with K. E. Wilzbach (ANL), P. N. Cheremisinoff (New Jersey Institute of Technology, Newark), H. W. Elder (Tennessee Valley Authority, Muscle Shoals, AL), D. W. Rahol and A. M. Talbot (Huntington Alloys, Rosemont, IL), and personnel from Research-Cottre11, Somerville, NJ contributed greatly to this work. I would also like to thank H. S. Rosenberg of Battelle Columbus Laboratories, Columbus, OH for making his report available prior to publication; C. Y. Li (Cornell Untversity, Ithaca, NY) for helpful discussions concerning the proposed ANL program; and E. M. Stefansk1 (ANL) for her valuable edftorial advice on the manuscript.

\section{RLFERENCES}

1. Proceedings of Second International Lime/Ltmestone Wet Scrubbing Symposlum, U.S. Environmental Protection Agency, New Orleans, Louisiana, November 8-12, 1971.

2. Proceedings: Symposium on Flue Gas Desulfurization, Hollywood, Florida, November 1977, EPA-600/7-78 058a \& b, Vols. I \& II (March 1978).

3. Application of Scrubbing System to Low Sulfur/Alkaline Ash Coals, EPRI FP-595, Project 785-1, Prepared by Arthur D. Little, Inc. for Electric Power Research Institute, Flnal Report (December $1^{\text {n }}$.

4. Proceedings: Flue Gas Desulfurizatj on Sympois ium 1973, New Orleans, Loulsiana, May 14-17, 1973, National Environnental Research Center, PB-230 901, Part I \& II.

5. Proceedings of the American Power Conference, Illinols Institute of Technology Center, Chicago, IL, The American Power Conference, Vol. 41 (1979).

6. Proceedings: Sympostum on Flue Gas Desulfur1zation, Las Vegas, Nevada, March 1979, EPA-600/7-79-167a \& b, Vo1s. I \& II (1979).

7. M. Smith, EPA Ut1lity FGD Survey, EPA-600/7-79-022e (August 1979).

8. Env1ronmental Control Implications of Generating Electric Power from Coal, 1977 Technology Status Report, Append1x, Flue Gas Desulfurization in the United States, Prepared by Tennessee Valley Authority, Muscle Shoals, Alabama, for Argonne National Laboratory, ANL/ECT-3, Appendix F (December 1977).

9. R. A. Conway and R. D. Ross, Handbook of Industrlal Waste Disposal, Van Nostrand Reinhold Environmental Englneering Series pp. 528-529 (1979). 
10. The McIlvaine Scrubber Manual, Vo1. IV, The McIlvaine Company, Northbrook, Illinois (1978).

11. R. S. Madenburg, D. M. Paulsrude, and C. H. Sherman, Cltrate FGD Processes to be Tested at Coal-fired Industrlal Power Plants, 1977 Energy Management Guidebook, p. 19 (1977).

12. F. H. Ford, Flue Gas Desulfurization Trends, Power Eng., p. 48 (December 1976).

13. I. Miller, Dry Scrubbing Looms Large In $\mathrm{SO}_{2}$ Cleanup Plans, Chem. Eng., N.Y., P. 52 (August 1979).

14. Flue Gas Desulfurization by Dry Scrubbing in Spray Dryer Absorbers, Niro Atomizer, Inc., Columbia, Maryland (1978).

15. L. A. Midkiff, Spray-Dryer System Scrubs S0 2 , Power, p. 29 (January 1979).

16. E. Baakke, Flue Gas Desulfur1zation for Industrial Coal Fired Bollers, presented at the Symposium on Industrial Coal Utilization, Charlestown, SC, Apr11 17-18, 1980.

17. W. L. Wells, G. T. Munson and E. G. Marens, Actual and Profected Materials Problems in LImestone and MgO Scrubber Processes, presented at 7 th Energy Technology Conference and Exposition, Washington, D. C., March 24-26, 1980.

18. S. Vasan, The Citrex Process for SO Removal in Coal-Fired Bollers, Air Pollution Control and Deslgn Handbook, Part II, P. N. Cheremisinoff and R. A. Young, Eds., Marce1 Dekker, Inc., New York, p. 889 (1977).

19. R. L. Gall and E. J. Plaseck1, The Double Alkali Wet Scrubbing System, Chem. Eng. Prog. $77(5), 72$ (1975).

20. John Papamarcos, Stack Gas Cleanup, Power Eng., p. 56 (June 1977).

21. The Status of Flue Gas Desulfurization Systems in the United States, periodic report prepared by PEDCo Environmental, Cincinnat, Ohio (1977).

22. H. S. Rosenberg, H. H. Krause, L. J. Nowack1, C. W. Klstler, and R. G. Rhudy, Operating Experience with Construction Materials for Wet Flue Gas Scrubbers, presented at $75 \mathrm{~h}$ Energy Technology Conference and Exposition (ET7), Washington, D. C., March 24-26, 1980.

23. S. Lundstrom, Flue Gas Desulfurization - Conceptual Process Design and Cost Estimates for Lime/LImestone Wet Scrubbing, National Swedish Environment Protection Board, Publication 1974:9E (1974).

24. T. C. E11 tott, $\underline{\mathrm{SO}}_{2}$ Removal from Stack Gases, Power, p. 51 (September 1974). 
25. G. L. Crow, Reheaters in Systems for Scrubbing Stack Gases, Mater. Perform. $14(7), 9$ (1975).

26. P. Chot and H. Rosenberg, Reheat Wet-Scrubber Stack Gas to Avoid Downstream Difficulties, Power, p. 40 (July 1979).

27. P. N. Cheremisinoff and R. T. Fellman, Optimizing $\mathrm{SO}_{2}$ Scrubbing Pro- $^{-}$ cesses, Power Eng., p. 54 (October 1974).

28. R. T. Fellman and P. N. Cheremisinoff, A Survey of Lime/Limestone Scrubbing for $\mathrm{SO}_{2}$ Removal, Air Pollution Control and Design Handbook, Part II, P. N. Cheremisinoff and R. A. Young, Eds., Marcel Dekker, Inc., New York, p. 813 (1977).

29. Chlorides and FGD Systems, Technical Bullet1n, Research-Cottre11, Utility Division, Somerville, New Jersey (1979).

30. A. B. Adams, Jr., Corrosion Problems with Wet Scrubbing Equipment, Resolving Corrosion Problems in Air Pollution Control Equipment, NACE, Houston, TX, p. 54 (1976).

31. E. C. Hoxie and G. W. Tuffne11, A Summary of Inco Corrosion Tests in Power Plant Flue Gas Scrubbing Processes, 1bid., p. 65.

32. P. C. Mockridge and D. W. McDowe11, Jr., Materials and Corrosion Problems in a Fly-ash Scrubbing System, Mater. Perform., p. 13a iApril 1974).

33. Ref. 10, p. 1001 .

34. L. A. Midkiff, New Trends Update FGD Systems, Power, p. 103 (June 1979).

35. J. Javetski, Solving Corrosion Problems in A1r-Pollution Control Equipment - Part I, Power, p. 72 (May 1978) and Part II, Power, p. 80 (June 1978).

36. H. T. Michels and E. C. Hoxie, How to Rate Alloys for SO 2 Scrubbers, Chem. Eng., N.Y., p. 161 (June 1978).

37. W. Gilbert, Selecting Materlals for Wet Scrubbing Systems, Pollut. Eng., P. 28 (August 1973).

38. N. T. Mistry, Material Selection for Gas Scrubbers, Mater. Perform., p. 27 (April 1976).

39. G. T. Pail1, Corrosion Resistant Materials for $\mathrm{SO}_{2}$ Scrubbers, Power Eng., p. 54 (May 1978).

40. Report on Materlals of Construction for Flue Gas Desulfurization Systems, prepared by Chemico Alr Pollution Control Corporation, New York (1979). 
41. T. G. Gleason, How to Avold Scrubber Corrosion, Chem. Eng. Prog. 71 (3), p. 43 (1975).

42. G. L. Crow and H. R. Horsman, Review of Corrosion in Prototype Units while Scrubbing Stack Gases with Lime/Limestone Slurrles, NACE Corrosion/80, Paper \$274 (1980).

43. E. A. Tice, Corrosion Tests in Flue Gas Desulfurization Processes, Mater. Perform., p. 26 (Apr11 1974).

44. INCO, International Nickel Company, New York, Corrosion in SO Exhaust Gas Scrubbers -- Nickel-Containing Alloys to the Rescue, N1ckel Top. 31(2), 7 (1978).

45. K. Saugimoto and Y. Sawada, The Role of Alloyed Molybdenum in Austenitic Stainless Steels in the Inhibition of Pitting in Neutral Halide Solutions, Corrosion 32(9), 347 (1976).

46. T. Kodama and J. R. Ambrose, Effect of Molybdate Ion on the Repassivation Kinetics of Iron in Solutions Containing Chloride Ions, Corrosion $33(5)$, p. $155(1977)$.

47. E. A. Lislvols, Corrosion Resistance of Types 316 and 317 Stainless Steels in Simuiated $\mathrm{SO}_{2}$ Scrubber Environment, J. Electrochem. Soc. 124(12), 1887 (December 1977).

48. F. G. Hodge, High Performance Alloys Make Wet Scrubber Work, Chem. Eng. Prog., p. 84 (October 1978).

49. A. Adams and L. L. Oden, Some Observations on the Chlorination of Nicke1 200, Hastelloy $\mathrm{N}$, and Inconel 600 in the Presence of Sulfur, Mater. Perform., p. 25 ( $\Lambda$ pr11 1976).

50. J. R. Crum, E. L. Hibner and R. W. Ross, Jr., Corroston Resistance Cf High-Nickel Alloys in Sim:1ated So Scrubber Environments, NACE Corrosion/80, Paper $\$ 276$ (1980).

51. EPA Ut1l1ty FGD Survey: December 1978-January 1979, EPA-600/7-79-022c (May 1979).

52. EPA Ut1lity FGD Survey: October-December 1979, EPA-600/7-80-029a (January 1980).

53. D. W. Raho1, Huntington Alloys, personal communication (May 1980).

54. W. Ellison and R. S. Kaufmann, Toward Safe Scrubber-sludge Disposal, Power, p. 54 (July 1978).

55. R. P. Lee, Speclal Corrosion Testing Methods, Mater. Perform., p. 26 (July 1976). 